\title{
Phosphogenesis, aragonite fan formation and seafloor environments following the Marinoan glaciation
}

\author{
J. Okubo $^{\mathrm{a}, *}$, A.D. Muscente ${ }^{\mathrm{b}}$, G.L. Luvizotto $^{\mathrm{c}}$, G.J. Uhlein ${ }^{\mathrm{d}}$, L.V. Warren ${ }^{\mathrm{a}}$

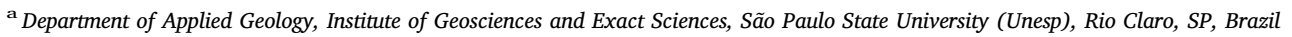 \\ b Department of Earth and Planetary Sciences, Harvard University, Cambridge, MA 02138, USA \\ ${ }^{c}$ Department of Petrology and Metallogenesis, Institute of Geosciences and Exact Sciences, São Paulo State University (Unesp), Rio Claro, SP, Brazil \\ ${ }^{\mathrm{d}}$ Institute of Geosciences, Federal University of Minas Gerais, Belo Horizonte, MG, Brazil
}

\begin{abstract}
A B S T R A C T
Carbonates in the Sete Lagoas Formation (São Francisco craton, Brazil) preserve a record of chemical, biological, and oceanographic changes that occurred during the Ediacaran Period. The base of this formation constitutes a post-glacial cap carbonate, which contains seafloor precipitates (carbonate and barite crystal fans) as well as various authigenic and diagenetic minerals (apatite, pyrite, and barite). Here, we present petrographic and geochemical data on this unit, and discuss the significance of its mineral association for marine environments following the Marinoan ('Snowball Earth') glaciation. For the first time, we report well-developed apatitic cements in a Neoproterozoic cap carbonate. Isopachous and intergranular void-filling cements encrust and surround seafloor-precipitated fan crystals that precipitated as aragonite. We propose a model for the origin of this mineral association, which relates phosphogenesis and aragonite fan formation to a single set of environmental conditions. According to this model, the boundary between oxic and anoxic conditions was located at or just below the sediment-water interface. Burial of iron (oxyhydr)oxides below this boundary liberated phosphate to pore water and provided fuel for iron reduction. Iron reduction released $\mathrm{Fe}^{2+}$, which inhibited nucleation of carbonate and allowed for aragonite growth on the seafloor. Concurrently, 'iron-pumping' shuttled phosphate from the water column to the sediment, and perhaps in conjunction with organic phosphorus remineralization via anaerobic microbial pathways, created conditions conducive to phosphate mineralization. This model corroborates the hypotheses that aragonite crystal fan formation requires the presence of an inhibitor to carbonate nucleation, in addition to high alkalinity, and that $\mathrm{Fe}^{2+}$ serves as this inhibitor. Overall, our work documents a close association between aragonite crystal fan formation and phosphogenesis at the beginning of the Ediacaran, illuminates the paleoenvironments of cap carbonates with seafloor precipitates, and contributes to understanding of phosphogenesis following low latitude glaciations.
\end{abstract}

\section{Introduction}

The Ediacaran Period witnessed major changes in the Earth system, including a rise in the oxygen level of the atmosphere-ocean system (McFadden et al., 2008; Macdonald et al., 2013; Lenton et al., 2014; Laakso and Schrag, 2017) and the radiation of complex multicellular eukaryotic life (Xiao et al., 2014). Various lines of evidence indicate that these changes followed an intense period of global ('Snowball Earth') glaciation (Kirschvink, 1992; Hoffman et al., 1998). Glacial diamictites occur worldwide in the Neoproterozoic. In general, three glacial episodes-the Sturtian, Marinoan and Gaskiers glaciations-are recognized in this interval (Halverson et al., 2005), and a combination of geochronologic and paleomagnetic data (Evans \& Raub, 2011) indicate that the Sturtian and Marinoan glaciations extended to tropical latitudes (Meert and van der Voo, 1994; Trindade and Macouin, 2007). Although some glacial deposits show faceted and striated clasts and contain deformation structures caused by glacial flow (Deynoux, 1985; Hoffman \& Schrag, 2002; McMechan, 2000; Hoffman, 2011), some of the 'glaciomarine' units likely represent syntectonic mass-flow deposits (Eyles and Januszczak, 2004; van Loon, 2008).

Cap carbonates are continuous units of pure dolostone (and locally limestone), up to tens of meters thick (James et al., 2001; Hoffman \& Schrag, 2002; Corsetti \& Lorentz, 2006; Hoffman et al., 2007), which commonly overlie sharp contacts with glacial deposits and subaqueous mass flow deposits around the world. These units are interpreted as the primary sedimentary records of deglaciation (Hoffman et al., 1998;

\footnotetext{
* Corresponding author.

E-mail address: juokubo@rc.unesp.br (J. Okubo).
} 
Fairchild \& Kennedy, 2007). Sturtian cap carbonates are generally dark, finely laminated, organic- and iron-rich units with rhythmic and anastomosing laminae (Hoffman and Schrag, 2002). These successions sometimes contain roll-up structures, and generally have $\delta^{13} \mathrm{C}$ values > 0 (Kennedy et al., 1998; Corsetti \& Lorentz, 2006). Marinoan cap carbonates, in contrast, are typically less than $10 \mathrm{~m}$ thick and their representative features include macropeloids, stromatolites, barite crystals and tubestone structures (Kennedy, 1996; James et al., 2001; Hoffman \& Schrag, 2002; Jiang et al., 2006a). These features are commonly overlain by limestones rich in aragonite crystal fans and/or by deep-water fine-grained siliciclastics. A regional (Gaskiers) glaciation is dated at $580 \mathrm{Ma}$, but the geographic extent of this event remains a subject of debate (Myrow and Kaufman, 1999; Pu et al., 2016; Spence et al., 2016).

Three non-exclusive models can account for the origin of the cap carbonates. First, assuming that high atmospheric $p \mathrm{CO}_{2}$ levels were responsible for deglaciation (the Snowball Earth model), such conditions may have driven intense chemical weathering on the continents, which in turn, enhanced seawater alkalinity and promoted rapid precipitation of cap carbonates around the world (Hoffman et al., 1998; Hoffman \& Schrag, 2002; Higgins \& Schrag, 2003). Second, assuming that glaciation caused physical stratification in the ocean and created a strong surface-to-deep water carbon isotope gradient, post glacial upwelling or flooding may have delivered alkalinity-rich deep water to continental shelves and interior basins (the overturn or upwelling model), resulting in carbonate precipitation (Grotzinger \& Knoll, 1995; Kaufman et al., 1997; Ridgwell et al., 2003). Lastly, if extreme cold fostered inorganic carbon supersaturation in the ocean (methane model), methane oxidation could account for deposition of cap carbonates and their associated low carbon isotopic values (Kennedy et al., 2001; Jiang et al., 2003). Overall, these models provide insights into the possible oceanographic conditions associated with low latitude glaciation and illustrate the extreme environmental shifts associated with climate change.

Authigenic minerals provide invaluable information on the evolution of seawater, as they contain direct and indirect evidence of chemical inputs into the ocean and recycling within it (Kastner, 1999). Seafloor-precipitated carbonate crystal fans, generally pseudomorphs after aragonite, occur in many Neoproterozoic cap carbonates (Peryt et al., 1990; Kennedy, 1996; Hoffman et al., 1998; James et al., 2001; Hoffman \& Schrag, 2002; Nogueira et al., 2003; Lorentz et al., 2004; Pruss et al., 2008; Vieira et al., 2015). The environmental conditions that fostered their formation remain poorly understood. In general, aragonite fans form in conditions with neutral to alkaline seawater $\mathrm{pH}$, low average sedimentation rates, and low influx of detrital clastic material (Sumner \& Grotzinger, 2004). During deposition of cap carbonates, high alkalinity and the presence of inhibitors to carbonate nucleation (perhaps $\mathrm{Fe}^{2+}$ under anoxic conditions) may have also contributed to aragonite fan formation. By limiting nucleation, the inhibitors promote a buildup of alkalinity. Under these conditions, mineral growth is localized to preexisting surfaces on the seafloor, where aragonite incorporates dissolved inorganic carbon (DIC) and develops into encrusting cements.

Barite represents another major component of Neoproterozoic cap carbonates. Dolostone units overlying Marinoan glacial diamictites around the world contain barite crystal fans as well as various forms of diagenetic barite (Kennedy, 1996; Jiang et al., 2006a,b; Shields et al., 2007; Macdonald et al., 2009; Zhou et al., 2010; Hoffman \& Halverson, 2011; Macdonald \& Jones, 2011; Bergmann et al., 2013). These barites variably signify primary seafloor cements and chemical sediments, which formed in deep-water settings (below storm wave base) during marine transgression (Kennedy, 1996; Hoffman \& Halverson, 2011) as well as products of fluid mixing in sedimentary sulfate-methane transition zones influenced by gas-hydrate destabilization (Kennedy et al., 2001; Jiang et al., 2003, 2006a,b; Shields et al., 2007; Cui et al., 2017).

Notably, the cap carbonate record of authigenic minerals does not extend to calcium phosphate minerals (Hoffman et al., 2011), even though P:Fe ratios in iron formations and geochemical models suggest that high dissolved phosphate concentrations developed during and/or in the aftermath of low-latitude glaciations (Planavsky et al., 2010; Laakso \& Schrag, 2017). The dearth of phosphorite in cap carbonates stands at odds with the cap carbonate models. Riverine input and ocean upwelling constitute the major fluxes of phosphorus to shelf settings conducive to phosphogenesis, the authigenic and early diagenetic precipitation of phosphate with sediment (Glenn \& Arthur, 1990; Glenn et al., 1994; Papineau, 2010). As cap carbonate deposition may have resulted from enhanced post-glacial continental weathering and deep water upwelling, the absence of phosphorite is striking. High alkalinity-which sequesters $\mathrm{Ca}$ via $\mathrm{CaCO}_{3}$ precipitation and generally limits the rate of phosphate precipitation (Briggs \& Wilby, 1996)—may account for this pattern.

In this contribution, we describe the association of seafloor precipitates (carbonate and barite crystal fans) and authigenic and diagenetic minerals (apatite and barite) within the cap carbonate unit in the lower part of the Sete Lagoas Formation (central São Francisco craton) near Januária, central Brazil. In addition, we discuss its significance for global seawater chemistry and sedimentary environments following Neoproterozoic glaciations. Overall, the presence of apatite in this cap carbonate has direct implications for the origin of the seafloor precipitates as well as indirect implications for the phosphorus cycle during the Cryogenian-Ediacaran critical transition.

\section{Geological setting, stratigraphy, and depositional age}

In east-central Brazil, the São Francisco craton (SFC) is related to the Brasiliano-Pan African orogenies (Trompette, 1994; Brito Neves et al., 1999; see Fig. 1A). The cratonic cover Bambuí basin is surrounded by the late Neoproterozoic Araçuaí and Brasília fold belts in its central portion, and was formed at the end of the Neoproterozoic (Chang et al., 1988; Pimentel et al., 2001, 2011; Martins-Neto, 2009; Reis \& Suss, 2016). Overall, the Bambuí Group constitutes a thick (up to $2000 \mathrm{~m}$ ) succession of carbonate and siliciclastic rocks (Fig. 1B and C), which is subdivided, from base to top, into the Sete Lagoas (SLF), Serra de Santa Helena, Lagoa do Jacaré, Serra da Saudade, and Três Marias formations (Dardenne et al., 1978; Fig. 1C). In some places, the SLF is underlain by the glaciogenic Jequitaí Formation. Regardless, the SLF is comprised of limestone and dolostone (containing well preserved stromatolites) interbedded with shale and mudstone (Vieira et al., 2007). Above the SLF, the Serra de Santa Helena Formation contains shale, siltstone, and sandstone with subordinate limestone, and the Lagoa do Jacaré Formation consists of abundant black and grey limestone, marl, and shale, marking a resumption of carbonate production. Siliciclastic units predominate near the top of the Bambuí Group succession, represented by siltstone and shale of the Serra da Saudade Formation and the sandstone of the uppermost Três Marias Formation (Chiavegatto, 1992).

The carbonates of the SLF were deposited within a shallow carbonate platform just above an erosive discordance with cratonic basement rocks or in conformity with glaciogenic deposits of the Jequitaí Formation. In the vicinity of Januária (Fig. $1 \mathrm{~A}$ and $\mathrm{B}$ ) in the central portion of SFC, the Bambuí succession overlies Paleoproterozoic migmatites and gneisses that constitute the Januária high (Fig. 1B). In this region, the SLF consists mainly of grainstone, microbialite, dolostone, and mudstone. Intraformational and hydrothermal breccias are present in the middle part of the unit and rare black chert occurs as thin (less than $5 \mathrm{~cm}$ ) layers and nodules within the grainstone. In general, black chert likely precipitated during diagenesis in anoxic sedimentary microenvironments influenced by microbial activity (Xiao et al., 2010; Muscente et al., 2015).

The lowermost portion of the SLF resembles a typical post-glacial cap carbonate succession (Vieira et al., 2007), and despite absence of the glaciogenic Jequitaí Formation in some sections of the São Francisco craton, geochronological and paleontological data constrain the 

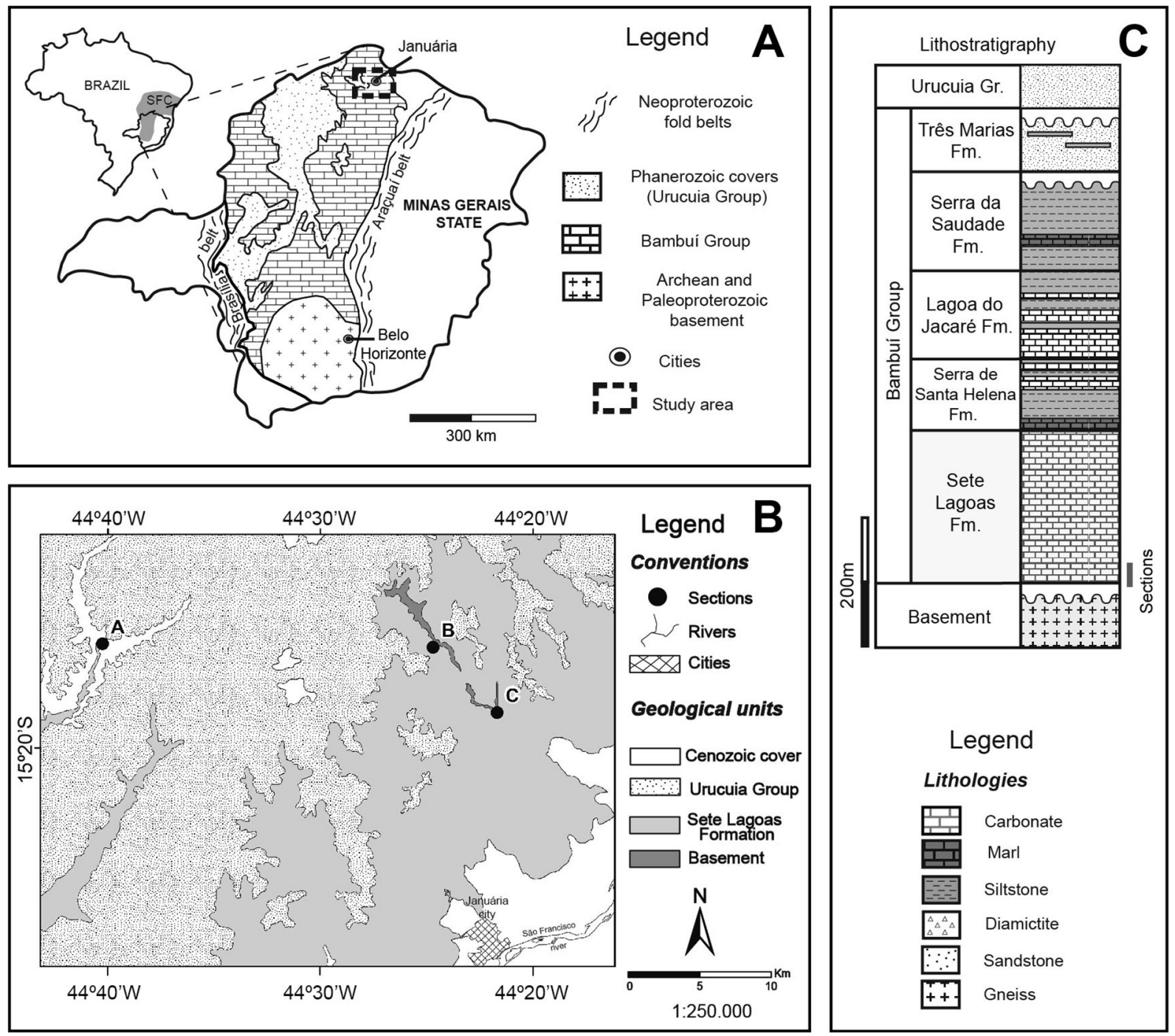

Fig. 1. A) Location of the SFC and the Bambuí Group in the Januária region. B) Geologic map of the SLF in the study area. The sections are presented in Fig. 2. A: Borrachudo section; B: Sapé section; C: Riacho da Cruz section. C) Stratigraphic section of the Bambuí Group in the SFC with the location of the sections presented in Fig. 2. Gr. - Group, Fm. - Formation.

age of the cap carbonate to the Late Neoproterozoic. U-Pb LA-ICP-MS dating of detrital zircon populations collected above the cap carbonate provide a maximum depositional age between $610 \mathrm{Ma}$ (Rodrigues, 2008) and $550 \mathrm{Ma}$ (Paula-Santos et al., 2015) for the middle part of the SLF. In addition, the tubular shelly fossil Cloudina-a potential Ediacaran index fossil (Xiao et al., 2016)—occurs in the middle portion of the SLF in the Januária region (Warren et al., 2014), confirming a terminal Ediacaran age for that part of the unit. Occurrence of the fossil Corumbella-known from upper Ediacaran strata in Brazil, Paraguay, and the US (Hahn et al., 1982; Hagadorn \& Waggoner, 2000; Warren et al., 2011)—likewise corroborates this age. Lastly, planktonic acritarchs with external morphological projections and ornamentation suggest an Ediacaran age for the base of the Bambuí Group (Cruz and Nobre-Lopes, 1992). Other biotic elements in the SLF-microbialites (e.g., Conophyton and thrombolites), silicified microbial mats, and prokaryotic and algal microfossils-do not help to further refine this age (Marchese, 1974; Fairchild \& Subacius, 1986; Fairchild et al., 1996; Nobre \& Coimbra, 2000), but do represent common elements in terminal Neoproterozoic successions worldwide (Xiao et al., 2014; Muscente et al., 2015).

The maximum depositional age of the cap carbonate and its relative stratigraphic position remain uncertain. In general, the lithological features (e.g., crystal fans and basal pink dolomites), carbon and oxygen isotope profiles, and ${ }^{87} \mathrm{Sr} /{ }^{86} \mathrm{Sr}$ ratios $(0.7074-0.7076)$ of the unit best match those of Marinoan cap carbonates (Halverson et al., 2005; Hoffman et al., 2007; Caxito et al., 2012). A controversial Pb-Pb isochron age of $740 \pm 22$ Ma taken from the base of the SLF suggests that the formation was deposited following the Sturtian event (Babinski et al., 2007; Misi et al., 2007; Kaufman et al., 2009). However, the data associated with this age may reflect alteration of the original $\mathrm{Pb}$ isotope signal (Caxito et al., 2012) in response to widespread post-burial remagnetization during a large-scale fluid percolation event in the São Francisco craton (Babinski et al., 1999; D'Agrella-Filho et al., 2000). If so, the $\mathrm{Pb}-\mathrm{Pb}$ age may not be reliable. Regardless, the succession likely contains an unconformity between the lower and upper portions of the SFL (Paula-Santos et al., 2015; Uhlein et al., 2016). Although field surveys have not yet convincingly documented such a feature, a shorter rather than a longer hiatus would account for the limited variation observed in the Bambuí Group strontium isotope curve through the SLF succession (Caxito et al., 2012). Thus, the best available data supports an Ediacaran age for the cap carbonate. The lithology of the cap carbonate-particularly, the presence of crystal fans-points to a Marinoan age, and no substantial carbonate units with similar features occur over Gaskiers glaciogenic deposits. Also, reports of anomalous $\Delta^{17} \mathrm{O}$ isotope values within the Sete Lagoas cap carbonate, similar to those found in South China and Mauritania, reinforce the post- 
Marinoan context (Crockford et al., 2017). For these reasons, we infer the existence of an unconformity between the base and the middle portion of the sequence, representing an 85 million-year hiatus.

Phosphatic rocks, minerals, and biosedimentary structures occur in the SLF and in the Salitre Formation (Una Group) of the Irecê Basin, which is correlated with the SLF on the basis of chemostratigraphic data (Misi and Veizer, 1998). Vieira et al. (2015) reported apatite as an accessory diagenetic mineral phase in the SLF cap carbonate, but did not describe its petrography or origin. The most substantial phosphatic deposit in the unit occurs in its middle part, where microbial laminated mud-rich siltstone and intraclastic grainstone contain pristine and reworked phosphorite, including discontinuous phosphatic laminae and in situ, fine to medium sand-size, ellipsoidal peloids (Drummond et al., 2015). This phosphorite purportedly formed in response to windblown delivery of phosphorus adsorbed on aeolian iron (oxyhydr)oxide and clay (Drummond et al., 2015). In the correlated Salitre Formation, phosphate digitate stromatolites are found at the top of peritidal carbonate cycles, and likely formed when microbial organisms inhabiting intertidal flats created redox and sedimentological conditions conducive to phosphorus mineralization, for instance, by storing and releasing phosphate (Caird et al., 2017). Regardless of the exact processes involved in phosphogenesis in each of these cases, the data are suggestive of high phosphate availability through deposition of the Sete Lagoas and Salitre formations.

\section{Material and methods}

Three stratigraphic sections were measured in the central part of the SFC near Januária city (Figs. 1B and 2). In all sections, the SLF directly overlies the Paleoproterozoic basement. Rock samples from the Borrachudo and Riacho da Cruz sections were prepared as slabs and thin sections, which were then analyzed via polarized light microscopy and scanning electron microscopy (SEM). All SEM analyses were conducted at an accelerating voltage of $15 \mathrm{keV}$ and a working distance of $10 \mathrm{~mm}$ and resulted in secondary electron (SE) and backscattered electron (BSE) images with compositional contrast (Muscente and Xiao, 2015). In addition, several samples were carbon-coated for electron probe microanalysis (EPMA) with X-ray energy dispersive X-ray spectroscopy (EDS) and X-ray wavelength dispersive spectroscopy (WDS). The EPMA work was conducted at the Department of Petrology and Metallogeny (São Paulo State University), using a JEOL JXA 8230 superprobe equipped with 5 WDS spectrometers and a panchromatic cathodoluminescence system (XM-26730PCL). All WDS and EDS data (including elemental maps) were acquired at accelerating voltages of $15 \mathrm{keV}$ and probe currents of 20nA in order to identify major elements: $\mathrm{Fe}(\mathrm{K} \alpha), \mathrm{Ca}(\mathrm{K} \alpha), \mathrm{Mg}(\mathrm{K} \alpha)$, Ba $(\mathrm{L} \alpha), \mathrm{S}(\mathrm{K} \alpha), \mathrm{Si}(\mathrm{K} \alpha)$ and $\mathrm{Al}(\mathrm{K} \alpha)$.

For carbon and oxygen isotopic analyses, carbonate powders were obtained via microdrilling of homogeneous samples (fractured, weathered, and mineral-filled zones were avoided). These powders were reacted with $100 \% \mathrm{H}_{3} \mathrm{PO}_{4}$ under $\mathrm{He}$ atmospheric conditions. The carbon and oxygen isotopic compositions of the $\mathrm{CO}_{2}$ extracted through the process were then measured in a Delta Advantage mass spectrometer in the Federal University of Paraná. Isotopic results are reported in the conventional per-mil delta notation $\left(\delta^{13} \mathrm{C}_{\text {carb }}\right.$ and $\left.\delta^{18} \mathrm{O}_{\text {carb }}\right)$ with respect to Vienna Pee Dee Belemnite (VPDB).

\section{Results}

Seafloor-precipitated cements were discovered in all studied sections (Figs. 2 and 3). Combined field, petrographic, and in situ geochemical analysis show that these fans variably consist of calcium carbonate (Figs. 3-5) and barite (Figs. 3 and 6). The precipitates evidently grew as radiating crystals (i.e., fans) oriented sub-parallel relative to the seafloor as well as upward-oriented (seafloor perpendicular) bed-forming crystals. Carbonate and barite crystal fans occur in rocks of the same facies near the base of the Sete Lagoas Formation.
Beginning a few meters above the base of the succession, carbonate fans occur in parallel-laminated beds, which vary from millimeters to decimeters in thickness (Fig. 3A and B). Barite fans, conversely, occur as irregular layers within microbial carbonate and laminated grainstone. These layers extend over laterally continuous areas between 10 and 15 square-meters, are generally $1-2 \mathrm{~cm}$ thick, and reach $15 \mathrm{~cm}$ thick in some strata exposed in the Borrachudo section (Fig. 2). With the exception of one layer in the Riacho da Cruz section, which bifurcates along the bedding plane (Fig. 3E), the strata containing barite fans are typically stratiform and have flat tops and bases (Fig. 3D).

The calcium carbonate and barite cements occur in close stratigraphic association. However, the relative succession of carbonate- and barite-containing layers varies among sections (Fig. 2). In the Borrachudo section, layers containing carbonate and barite cements alternate in the succession. Conversely, in the Sapé section, seafloor carbonate occurs exclusively within strata below those with barite fans, and in the Riacho da Cruz section, carbonate fans occur in strata $\left(\delta^{13} \mathrm{C}_{\text {carb, }}\right.$ $-3.76 \%$; $\delta^{18} \mathrm{O}_{\text {carb, }}-12.77 \%$ ) above those with barite precipitates $\left(\delta^{13} \mathrm{C}_{\text {carb, }}-3.15 \%\right.$; $\delta^{18} \mathrm{O}_{\text {carb, }}-8.68 \%$ ) .

Electron imaging and in situ geochemical analysis generated mineralogical and geochemical data on the various minerals in the unit. As observed from cross sections of bedding surfaces, the fan-forming crystals emanate within horizontal and irregular clay layers (Fig. 3F) with high $\mathrm{Al}$ and $\mathrm{Si}$ contents relative to the $\mathrm{Ca}$ - and $\mathrm{Mg}$-rich calcite matrix of the limestone (Fig. 6). The seafloor barite cements consist of radiating blade-shaped crystals, which are generally between $200 \mu \mathrm{m}$ and $3 \mathrm{~cm}$ in length and about $50 \mu \mathrm{m}$ in thickness (Figs. 3F and 6). In contrast, the carbonate cements consist of (sub-)acicular (needle-like) crystal units with hexagonal $(\sim 200 \mu \mathrm{m}$ diameter $)$ cross sections (Figs. 3B, C and 4A) and square terminations (Fig. 5D), like aragonite crystals. Each crystal unit, however, consists of mosaic calcite, and is comprised of numerous small equant crystals (Fig. 4B). Polysynthetic twinning of the mosaic crystal units is common. In some layers, the calcite contains a markedly higher concentration of $\mathrm{Mg}$ than the surrounding limestone matrix (Fig. 8). Elsewhere, the mosaic units are surrounded by a high-Mg calcite matrix (Fig. 5C).

Besides assorted detrital (quartz, zircon, rutile, and clay - similar to those described by Bergmann et al., 2013) grains and barite and carbonate crystal fans, the matrix of the Sete Lagoas cap carbonate contains three conspicuous forms of sedimentary minerals: apatitic cements, microcrystalline barite, and pyrite (including pseudomorphs of iron oxide after pyrite, Fig. 7). The apatitic cements occur exclusively in layers with carbonate fan crystals (Fig. 4). In these layers, the phosphate minerals occur as isopachous cements encrusting detrital grains (Fig. 4D), as void-filling cements in intergranular spaces (Fig. 4C-E), and as thin laminae within Mg-calcite layers (Fig. 4C and E). The phosphate minerals also rarely occur as cements within rounded aggregates of quartz, calcite, and barite (Fig. 4F). In contrast to these cements, barite and pyrite were found in microcrystalline forms in virtually all samples. Both minerals fill void spaces and encrust apatite (Fig. 4D). In some places, the minerals occur in close association with each other, as exemplified by barite mixed with nodular pyrite/iron oxide (Fig. 7). Elsewhere, the minerals occur in relative isolation (Figs. 6, 7 and 9). Microcrystals of both types are found albeit rarely as inclusions within the mosaic calcite making up the carbonate fan crystals (Fig. 4).

\section{Discussion}

Petrographic and in situ geochemical analyses of the lower SLF near Januária corroborate previous studies, which documented aragonite and barite as major sedimentary minerals within Neoproterozoic cap carbonates (Hoffman et al., 2011). Carbonate crystal fans have been reported from other sections of the SLF (Caxito et al., 2012; Vieira et al., 2015; Kuchenbecker et al., 2016), and in general, are common sedimentary features of cap carbonates around the world (Corsetti et al., 


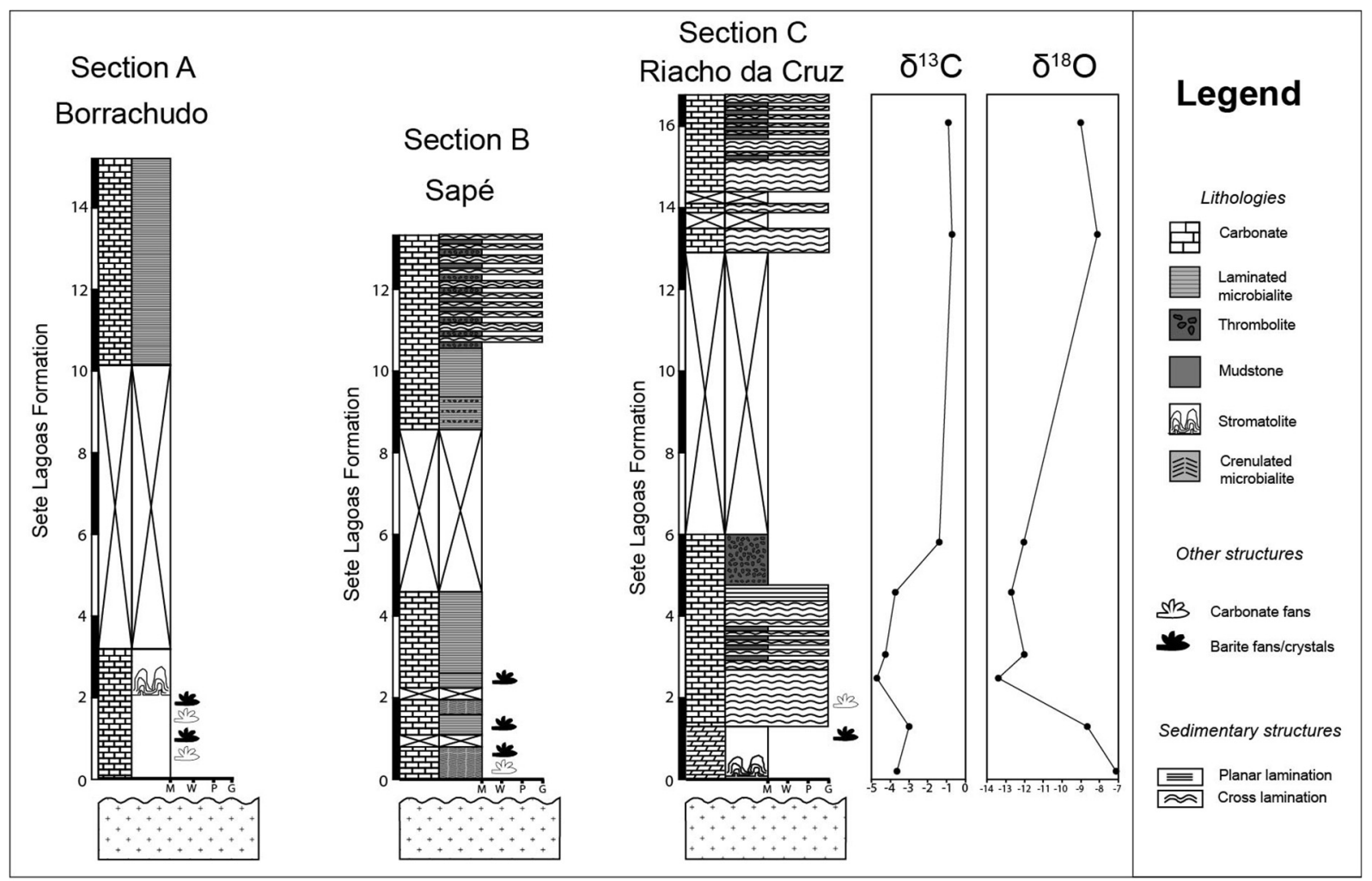

Fig. 2. Measured stratigraphic sections of the lower Sete Lagoas Formation. The columns show the stratigraphic positions of the aragonite fans and barite-bearing strata in relation to various lithologies. Note the prominent negative excursions in the carbon and oxygen isotopic curves near the base of the Sete Lagoas Formation. $\mathrm{M}=$ mudstone, $\mathrm{W}=$ wackestone, $\mathrm{P}=$ packstone, $\mathrm{G}=$ grainstone.

2004; Lorentz et al., 2004; Pruss et al., 2008), particularly those overlying Marinoan age glacial diamictites (Hoffman et al., 2011). The presence of well-preserved clusters of aragonite crystals (Figs. 3B, 8) suggests that fan formation in the SLF took place below storm wave base or in protected marine environments, where wave action did not exert a destructive influence, as previously suggested by Vieira et al. (2015). The pseudohexagonal habit of the crystals in these fans indicates that they originally precipitated on the seafloor as aragonite, which was altered to calcite during post-burial diagenesis (Pruss et al., 2008).

Marinoan cap dolostones commonly contain two types of barite (Hoffman et al., 2011)—primary seafloor precipitated crystal fans (Kennedy, 1996; Hoffman and Halverson, 2011) and early diagenetic barites often associated with tepee and tepee-like brecias (Jiang et al., 2006a, 2006b; Shields et al., 2007)—corresponding to the bladed crystals and microcrystalline forms of barite found in the Januária section of SLF, though we did not observe any demonstrable tepees or tepee-like structures. Detrital barite grains (Figs. 4 and 7) may represent products of reworking of fan crystals on the seafloor. In the Riacho da Cruz section, the barite fan crystals emanate within a clay layer (Figs. $3 \mathrm{~F}$ and 6), affirming that the crystals grew on the seafloor. This millimetric layer could represent a stylolite (Jiang et al., 2006a), produced by pressure-solution during compaction burial, or a pause in the sedimentation, leading to the decantation of the clay over a previous surface in low energy conditions.

Various processes contribute to barite formation and diagenetic alteration, each affecting the morphology and isotopic composition of the resulting crystals (Griffith and Paytan, 2012). In modern marine environments, barite generally forms via hydrothermal/cold seep, biogenic, and diagenetic pathways (Paytan et al., 2002; Shields et al., 2007). Whereas biogenic barite crystals that form in proximity to sinking particular matter and within organisms are typically smaller than $5 \mu \mathrm{m}$ and ellipsoidal in shape, hydrothermal barite generally consists of rosette-forming tabular crystals $20-70 \mu \mathrm{m}$ in diameter, and diagenetic barite occurs at tabular crystals $20-700 \mu \mathrm{m}$ in diameter (Paytan et al., 2002). Biogenic barite generally has a low preservation potential, as diagenetic dissolution in the sulfate-methane transition zone of the sedimentary column destroys biogenic crystals and precipitates barite with a diagenetic overprint (Zhou et al., 2015). Accordingly, the cap carbonate barites most likely represent hydrothermal, cold seep, and/or diagenetic minerals. The processes that promoted widespread precipitation of barite cements on the seafloor during deposition of the cap carbonates remain a subject of debate (Crockford et al., 2016).

For the first time, we report well-developed apatitic cements in a Neoproterozoic cap carbonate. We interpret the phosphatic minerals as products of penecontemporaneous authigenic mineralization for the following reasons. First, pyrite and microcrystalline barite encrust the apatite and fill voids within the phosphatic matrix, indicating that those minerals formed later in diagenesis within the sulfate reduction and sulfate-methane transition zones of the sedimentary column (Fig. 4D). Second, isopacheous phosphate cements encrusting detrital quartz grains and carbonate fan crystals affirm that the phosphate minerals formed prior to the later pyrite and barite (Fig. 4D). Lastly, apatitic cements bind quartz, calcite, and barite in rounded aggregates, which suggest that phosphate mineralization occurred at depths near the sediment-water interface permissive to sedimentary reworking and rounding of material (Fig. 4F), as exemplified by authigenic phosphoclasts in Ediacaran phosphorites (Muscente et al., 2015). Supplementary to these interpretations, subsequent to cementation of the intergranular space between aragonite fan crystals, phosphate mineralization evidently produced several thin laminae within Mg-rich calcite (Fig. 4C and E). These thin laminae point to restriction of phosphate mineralization to a particular depth in the sedimentary column, where sedimentary and geomicrobiological processes concentrated phosphate beyond ordinary supersaturation levels and drove 

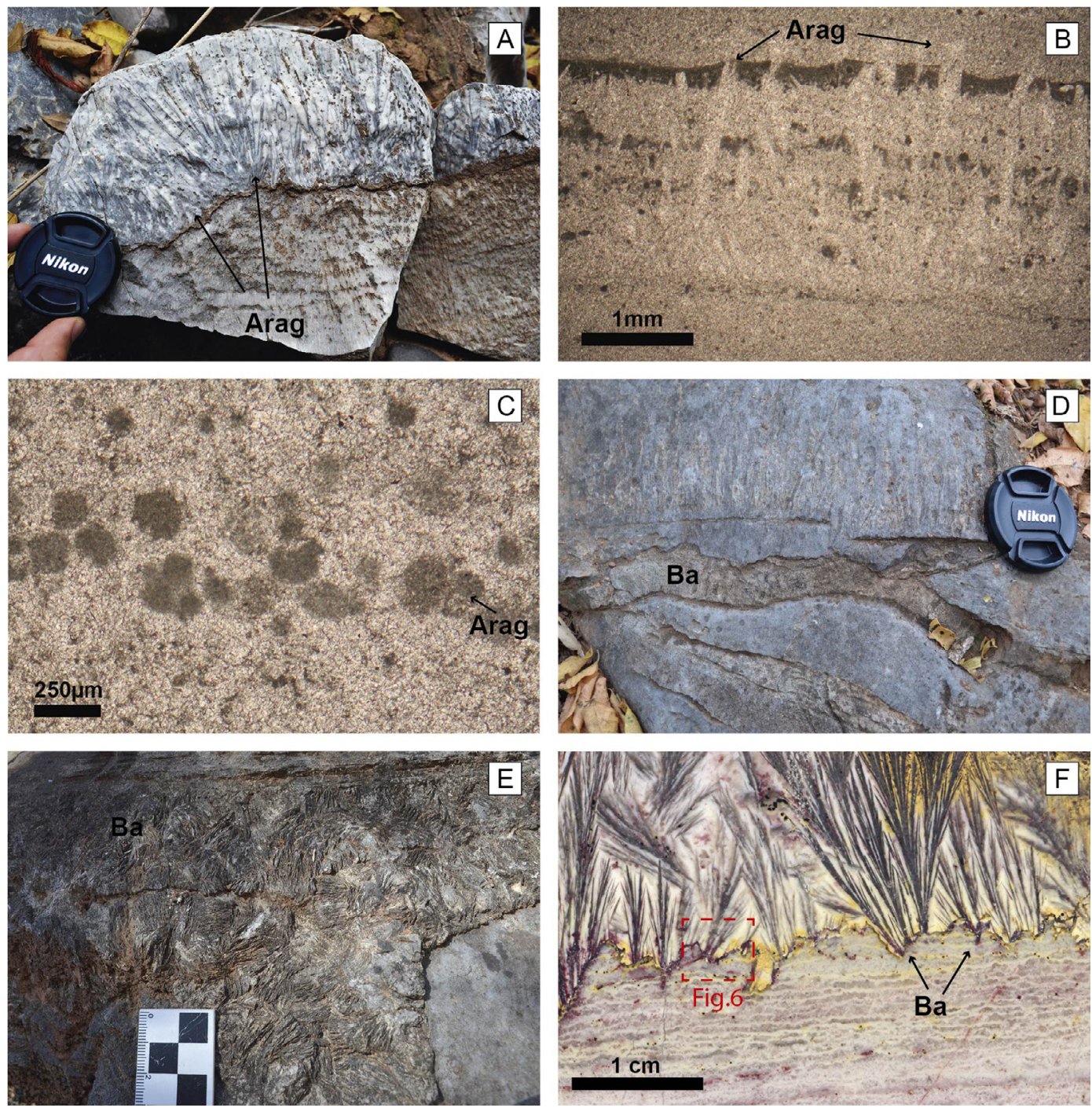

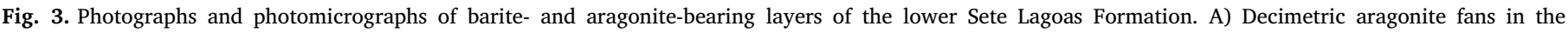
Borrachudo section. B-C) Thin sections of samples from the Riacho da Cruz section. Scale: $5 \mathrm{~cm}$. B) Millimetric-scale acicular/needlelike crystals forming centimetric aragonite crystal fans. Paralell nicols, $2.5 \times$. C) Cross section of aragonite fans, showing pseudohexagonal prisms. Paralell nicols, $10 \times$. D) Lateral view of barite (light grey) and aragonite (dark grey) bearing layers (Borrachudo section). Scale: $5 \mathrm{~cm}$. E) Detail of barite fans in the Riacho da Cruz section. F) Rock slab from the Riacho da Cruz section containing barite fans on a surface developed in carbonate/thrombolite substrate (Fig. 4). Arag: aragonite, Ba: barite.

phosphogenesis (Glenn et al., 1994). Overall, in terms of their sedimentology and petrography, the phosphate minerals in the SLF cap carbonate resemble authigenic and early diagenetic phosphatic features in typical phosphatic carbonates and phosphorites of Ediacaran and Cambrian ages (Creveling et al., 2014; Muscente et al., 2015).

This occurrence of apatite supplements other reports of phosphatic rocks, minerals, and biosedimentary structures in the SLF and correlated Salitre Formation (Drummond et al., 2015; Caird et al., 2017). Vieira et al. (2015) previously reported apatite as an accessory diagenetic mineral phase in the SLF cap carbonate, but those author did not describe substantial sedimentary phosphatization of the unit, and they not investigate the petrography of the apatite in any detail. Hence, phosphate mineralization constitutes a widespread but unexplored aspect of the SLF cap carbonate, which merits detailed discussion.

\subsection{Model of formation of these authigenic and diagenetic minerals}

The petrographic and geochemical data in this original report as well as data from other studies (Jiang et al., 2006a; Shields et al., 2007; Pruss et al., 2008) provide a basis for assessing the origin of the carbonate crystal fans and apatitic cements in the Marinoan cap carbonate at the base of the SLF. As we argue below, the minerals mutually illuminate the localized sedimentary and geobiologic processes involved in their formation as well as provide insights into their stratigraphic and geographic distribution. In addition, from a global to regional perspective, the co-occurrence of carbonate crystal fans and phosphate cements makes sense in terms of the cap carbonate formation and Ediacaran phosphogenic episode models, which attribute high seawater DIC, phosphorus, and calcium concentrations to enhanced continental weathering and ocean upwelling. Therefore, our work provides data pertinent to a variety of hypotheses (Grotzinger and Knoll, 1995; Kaufman et al., 1997; Hoffman et al., 1998; Hoffman and Schrag, 2002; Higgins and Schrag, 2003; Ridgwell et al., 2003; Muscente et al., 2015; Laakso and Schrag, 2017) regarding the low latitude glaciations of the Neoproterozoic.

Aragonite growing on the seafloor may have incorporated DIC from the water column, sediment, or both. Explanations for post-glacial cap carbonate formation generally implicate enhanced alkalinity in benthic marine environments, making the seawater DIC pool the plausible if not likely source of alkalinity. Remineralization of organic carbon via anaerobic microbial processes (iron, manganese, nitrate, and/or sulfate reduction) in the sediment may have further elevated bicarbonate 

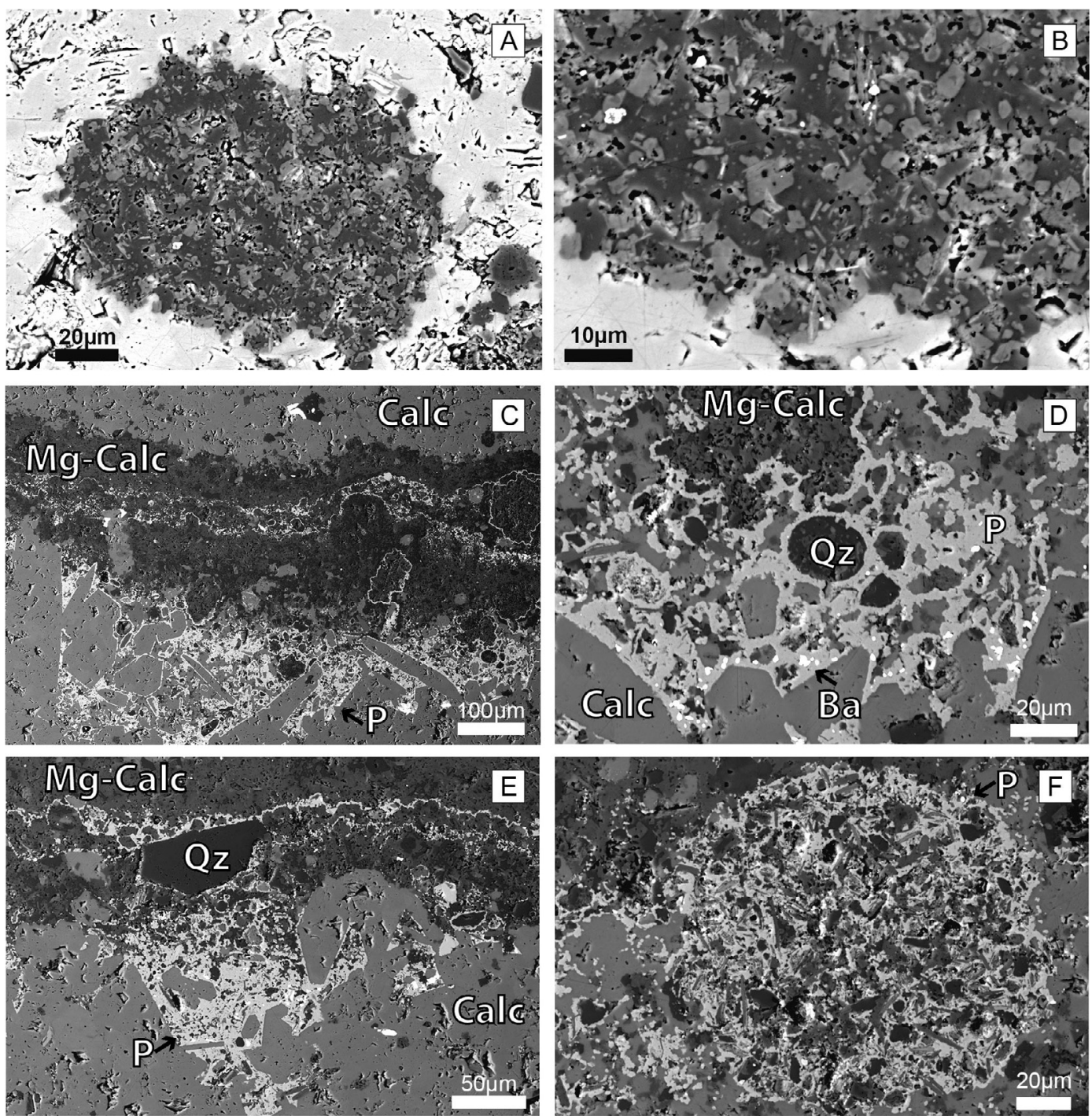

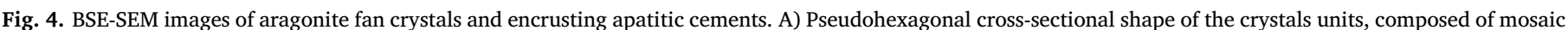

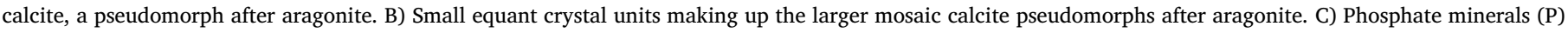

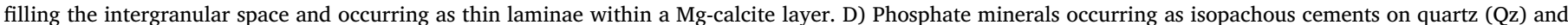

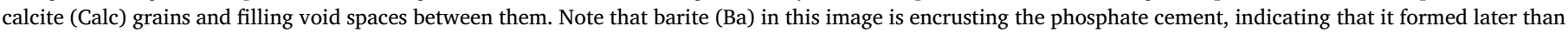

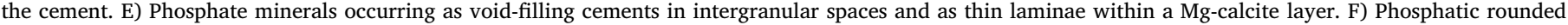
aggregate, composed of quartz, calcite and barite grains.

concentrations beyond supersaturation with respect to aragonite, and thereby, promoted formation of the mineral at the sediment-water interface. If so, the DIC contribution of organic carbon remineralization to aragonite crystal fan growth may have been most significant in seafloor environments, where the oxic-anoxic redox boundary was located near the sediment-water interface. Isotopic data, nonetheless, suggest that carbonate fans in other late Neoproterozoic carbonates principally derived alkalinity from isotopically well-mixed DIC reservoirs, most likely seawater (Pruss et al., 2008). Thus, the sedimentary DIC contribution to growth of the SLF aragonite may have been minor. Regardless of the alkalinity source, formation and growth of aragonite may additionally require the presence of transient inhibitors to carbonate (micrite) nucleation (Sumner and Grotzinger, 1996; De Leeuw, 2002; Pruss et al., 2008). The presence of iron minerals in interstices of fan units (Pruss et al., 2008)—like the pyrite and iron oxides (pyrite pseudomorphs) reported in this study-suggests that $\mathrm{Fe}^{2+}$ may have served this role during periods of cap carbonate deposition.

Phosphate follows a number of paths from the water column to sediment, and phosphogenesis may involve precipitation of dissolved pore water phosphate derived from one or more sources. The major fluxes of phosphate to the water column in modern marine shelf environments include upwelling of nutrient-rich seawater and riverine input of phosphate derived from continental weathering (Glenn et al., 1994; Föllmi, 1996). Given hypotheses regarding the source of alkalinity in cap carbonate deposition (Grotzinger and Knoll, 1995; Kaufman et al., 1997; Hoffman et al., 1998; Hoffman and Schrag, 2002; Higgins and Schrag, 2003; Ridgwell et al., 2003), we cannot exclude either of these possibilities or the possibility of aeolian input (Drummond et al., 2015). In any case, phosphorus burial occurs through burial of organic matter, iron (oxyhydr)oxide particulates, phosphatic skeletons, and detrital apatite (Glenn et al., 1994; Föllmi, 1996). The SLF cap carbonate contains no skeletal or detrital apatite grains besides the rounded aggregates of quartz, calcite, and barite (Fig. 4F), which are cemented by authigenic phosphate and likely formed via local reworking of phosphatized sediment. Phosphate mineral cements in the SLF, therefore, likely precipitated from pore water phosphate derived from two sources: remineralization of organically bound phosphorus and desorption of phosphate from surfaces of iron (oxyhydr)oxide particulates. 

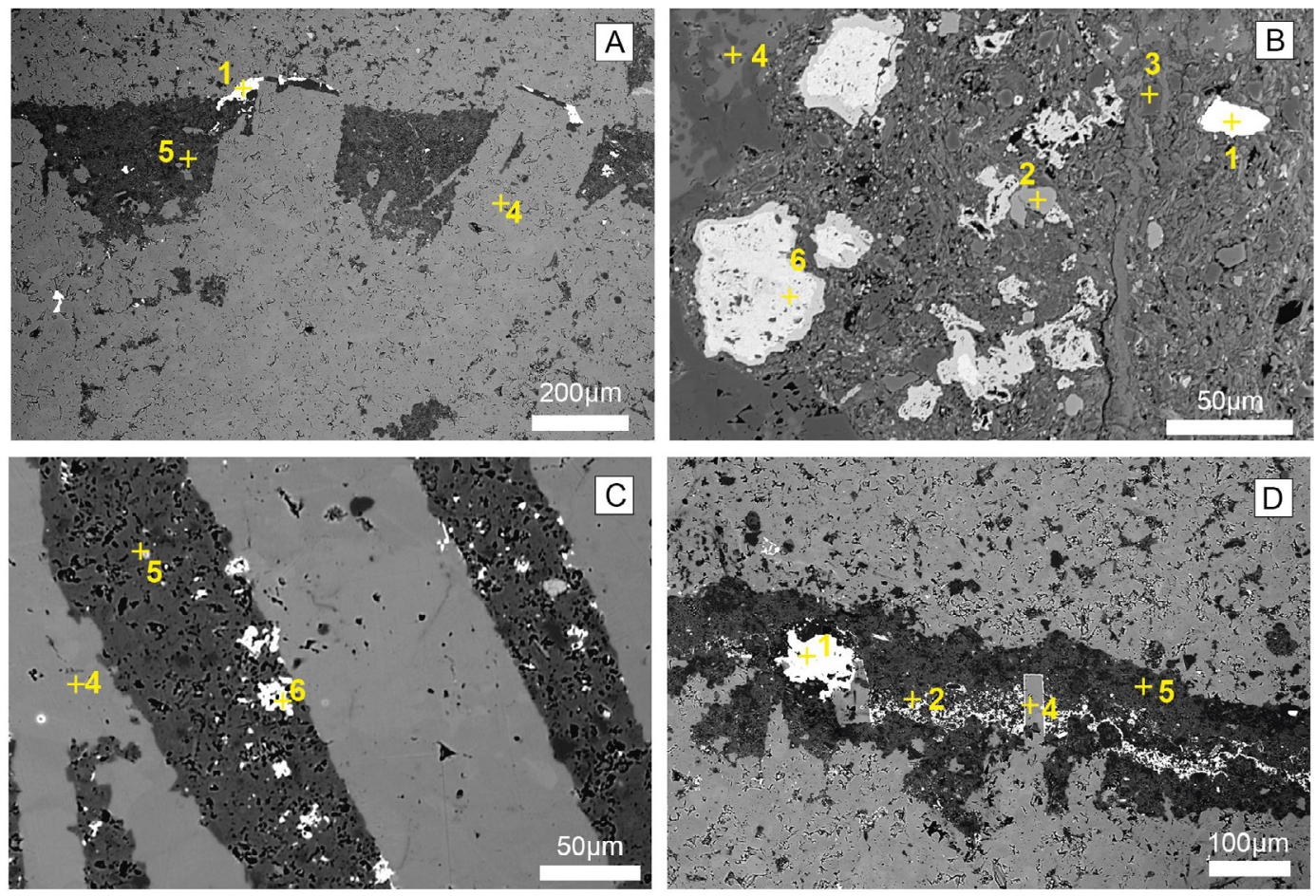

Representative EDS spectra of the mineral phases
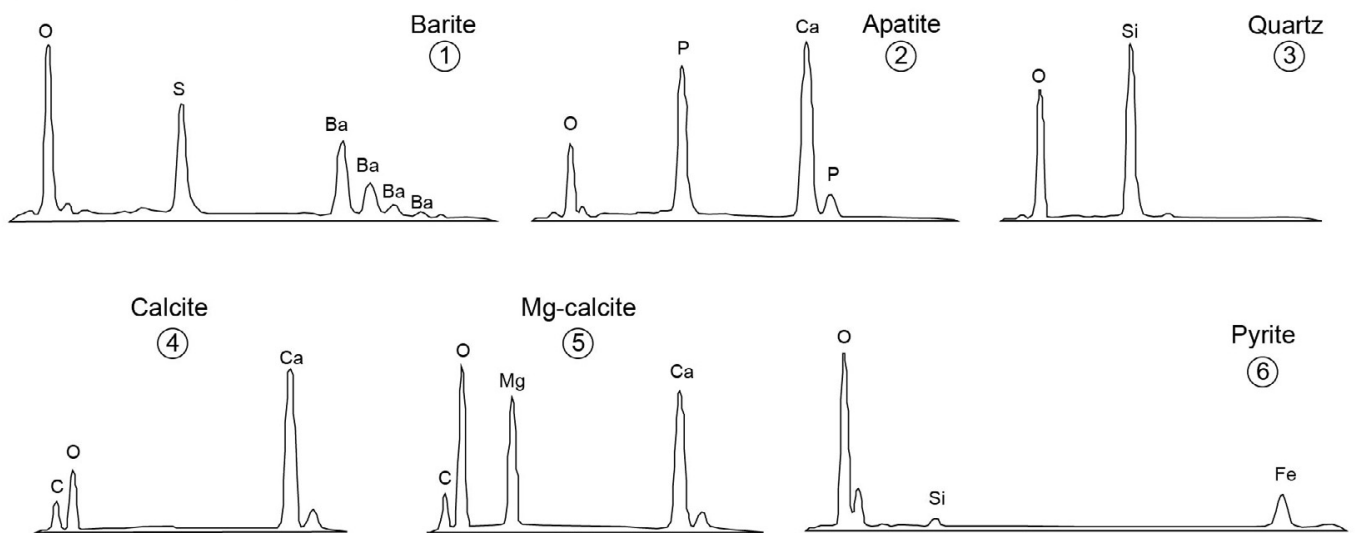

Fig. 5. BSE-SEM images and EDS spectra of the aragonite and barite fans. A) Barite crystals (1) encrusting pseudomorphed aragonite fan crystals. B) Clay surface between the matrix and the barite fans, which is composed of pyrite (6), phosphate (2), and barite (1). C) Details of carbonate fan crystals and inter-crystal spaces containing pyrite grains. D) Surface above the aragonite fans containing barite, diagenetic calcite, and phosphate cement. Numbers in the figure indicate the spot analysis.

In modern phosphogenic settings, the most efficient process of organic phosphorus remineralization is microbial sulfate reduction under anoxic conditions (Arning et al., 2009). The presence of pyrite and iron oxide (pyrite pseudomorphs) provide some evidence for this process. Likewise, these iron minerals affirm that dissolved iron was present during diagenesis, and is consistent with the inference that burial of iron (oxyhydr)oxide particulates below the oxic-anoxic boundary liberated phosphate to pore water. Thus, in general, the data suggest that phosphogenesis occurred near the redox boundary, where both processes maximally contributed to pore water phosphate supersaturation. This hypothesis is consistent with interpretations of other examples of Precambrian phosphogenesis (Nelson et al., 2010; Drummond et al., 2015; Muscente et al., 2015).

Iron (oxyhydr)oxide availability influences both aragonite fan formation and phosphogenesis. Dissolution of iron (oxyhydr)oxide particulates below the redox boundary liberates phosphate for phosphogenesis; microbial iron reduction fueled by these particulates produces DIC for aragonite growth; and both processes result in production of reduced iron $\left(\mathrm{Fe}^{2+}\right)$, which inhibits carbonate nucleation, and thereby, creates alkaline conditions conducive to aragonite growth on the seafloor. Despite these interrelated aspects of the mineralization processes, marine environments typically favor carbonate over phosphate mineralization, as high ambient bicarbonate concentrations limit the amount of calcium available for reaction with phosphate (Briggs and Wilby, 1996). Correspondingly, pH exerts a strong influence, as acidity destabilizes carbonate minerals, enhances calcium availability, and allows for phosphate precipitation under some circumstances (Allison, 1988).

In this context, a dichotomy presents itself. On the one hand, iron (oxyhydr)oxide burial and microbial metabolisms (carbon and phosphorus remineralization) create conditions conducive to both aragonite fan formation and phosphogenesis. Yet, on the other, microbial remineralization of carbon generates alkalinity, which generally precludes phosphate precipitation and prevents the two mineralization processes from occurring at the same time. A sedimentary model for the mineral association in the SLF cap carbonate must take this dichotomy into consideration. We infer (1) that aragonite crystal fan formation and 


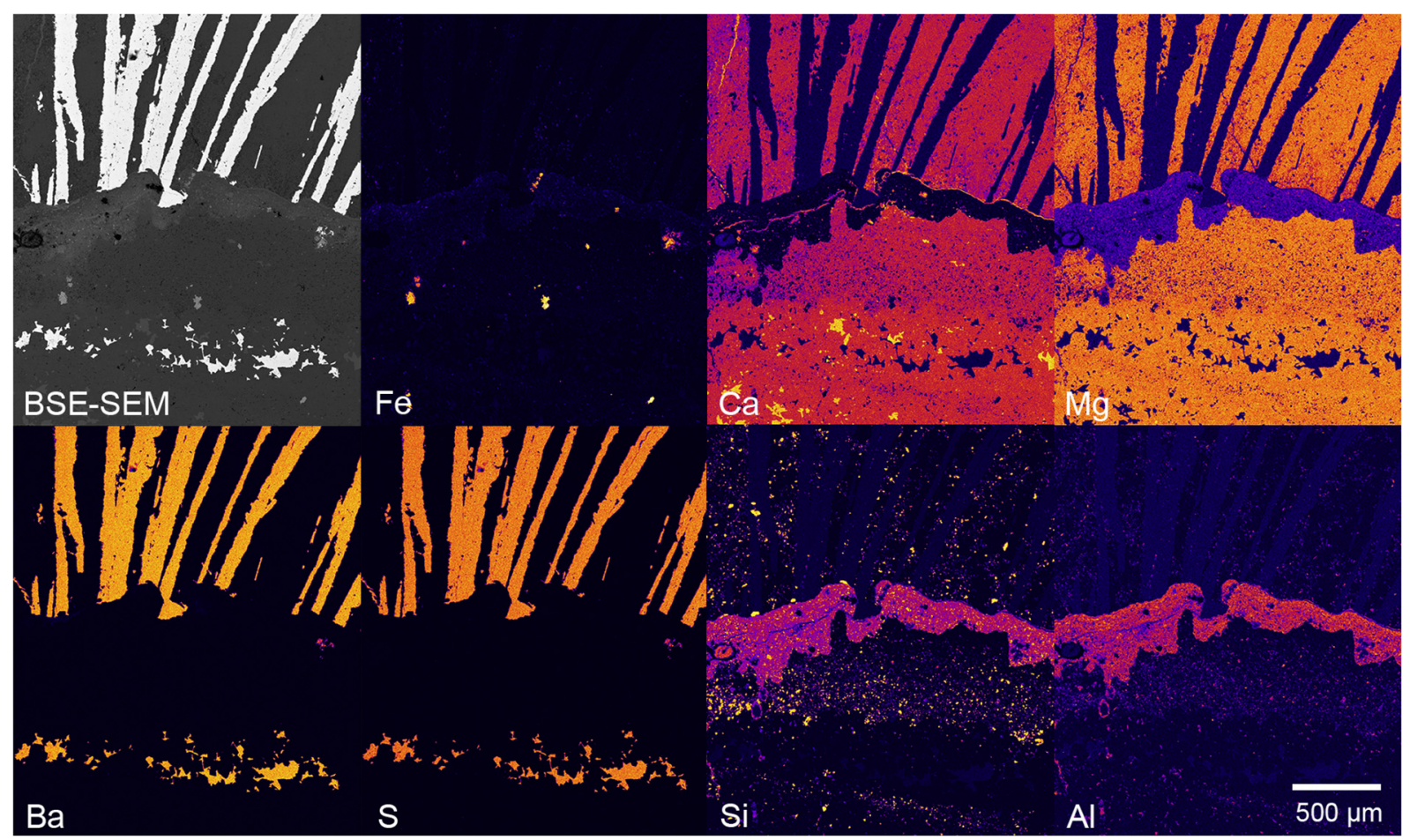

Fig. 6. BSE-SEM image and WDS elemental maps of the contact between the barite fans and the underlying microbialite (Riacho da Cruz section). This contact layer is rich in clays, accounting for its high $\mathrm{Al}, \mathrm{Si}$ and $\mathrm{Mg}$ contents. Detrital barite crystals are commonly found in the matrix of the microbialite facies, as seen below the clay contact layer.

phosphogenesis occurred in an environment, where the oxic-anoxic boundary was located near the sediment-water interface (Fig. 9), and (2) that burial of iron (oxyhydr)oxides below this boundary drove both phenomena through its influence on phosphate and $\mathrm{Fe}^{2+}$ concentrations. In the presence of $\mathrm{Fe}^{2+}$ generated via reduction of iron (oxyhydr) oxides, carbonate precipitation was largely restricted to preexisting surfaces of aragonitic crystals, which grew on seafloor cements. Following burial of these crystals within sediment with phosphate-rich pore water, phosphate precipitated on the crystals and in the intergranular spaces between them. The contributions of carbon and phosphorus remineralization to mineral growth were likely minor, at least following burial of the aragonite crystals fans, as those microbial

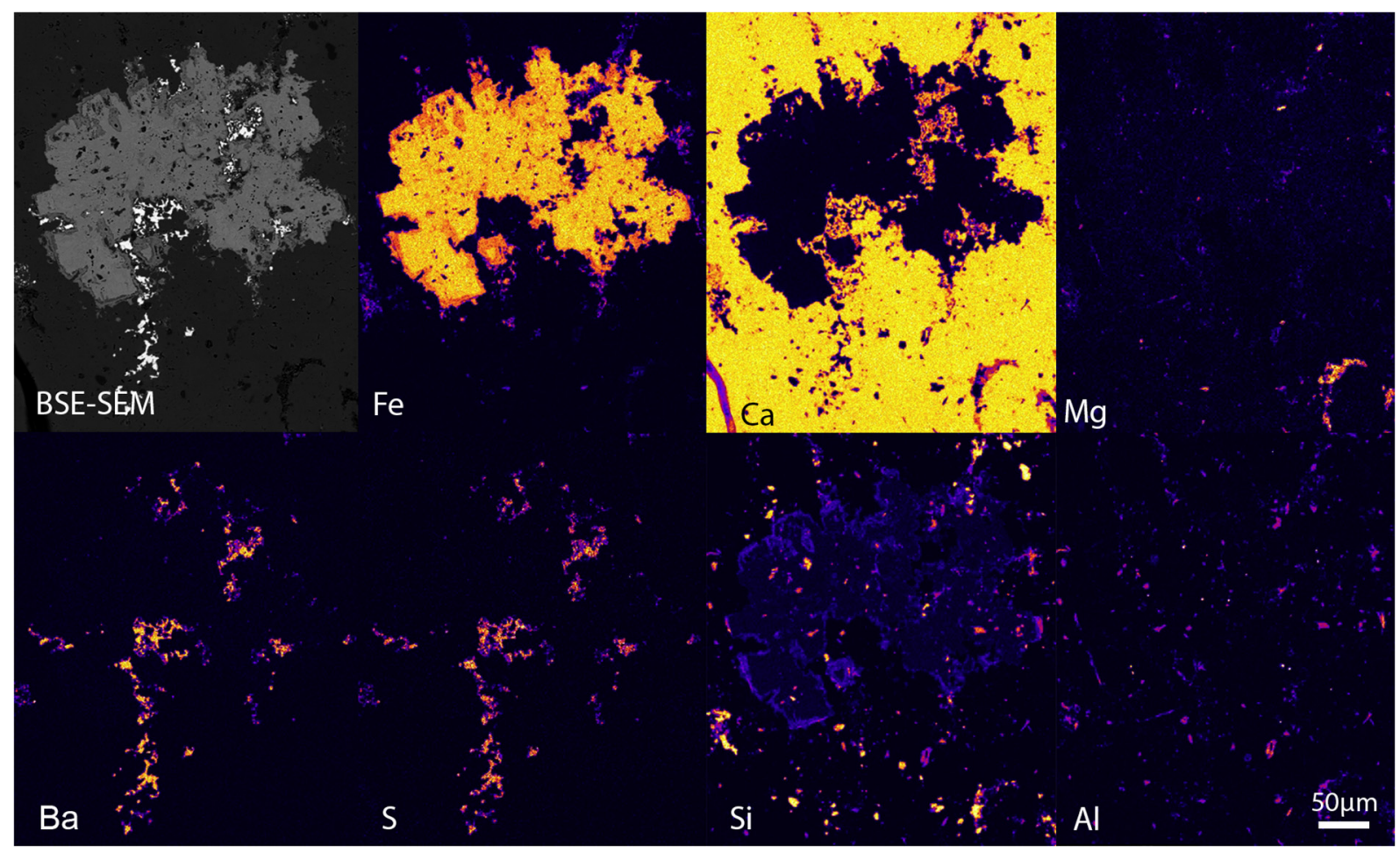

Fig. 7. BSE-SEM image and WDS elemental maps of barite associated with iron oxide pseudomorph of pyrite in microbialites (Borrachudo section). 


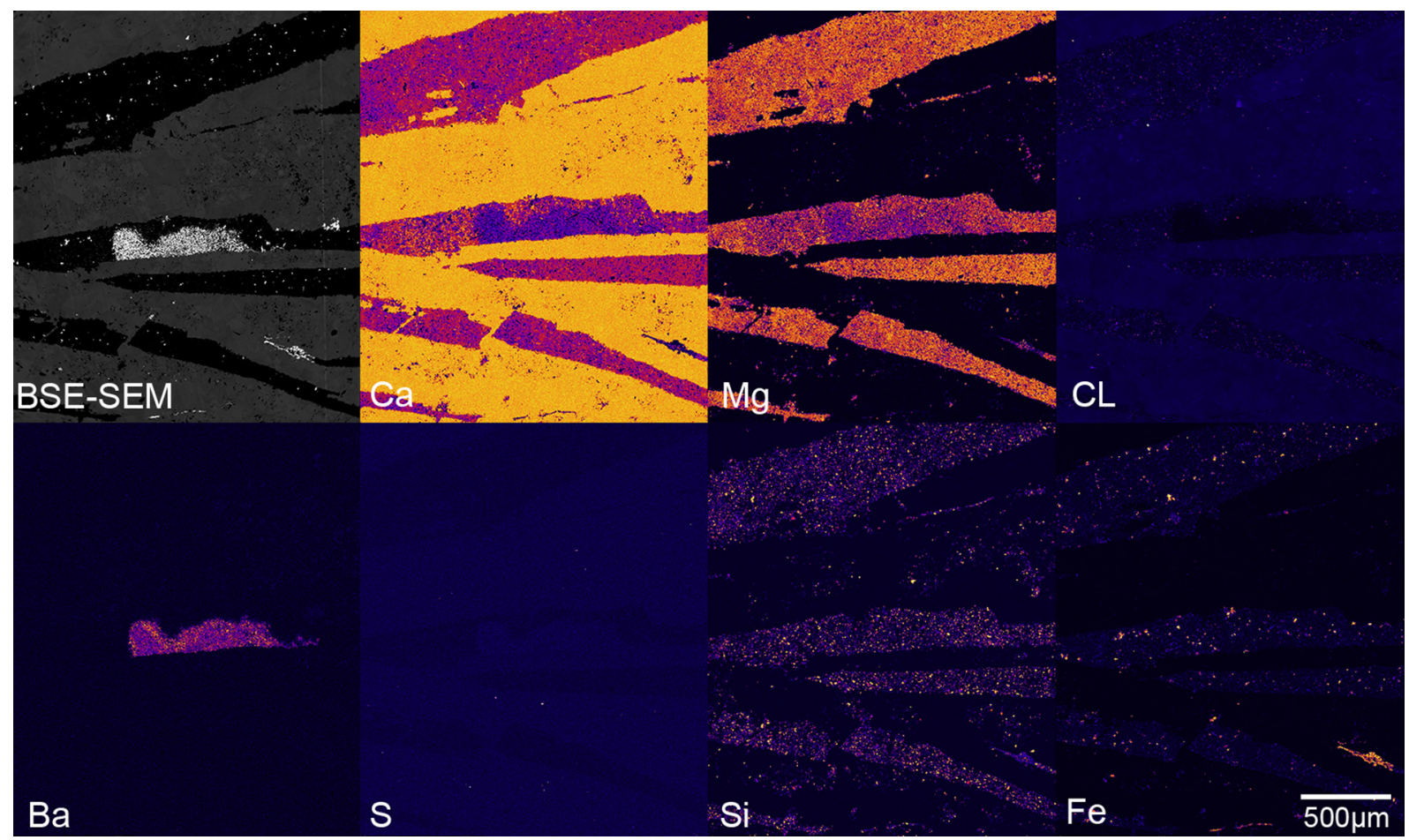

Fig. 8. BSE-SEM image and WDS elemental maps of aragonite fans from the Borrachudo section, showing barite inclusions with carbonate fan crystals.

processes produce alkalinity that kinetically limits phosphate precipitation. In any event, pyrite subsequently formed in the sulfate reduction zone. Diagenetic microcrystalline barite also formed after prolonged burial, most likely in the sulfate-methane transition zone (Zhou et al., 2015), though the origins of cap carbonate barite remain controversial (Crockford et al., 2016). The presence of pyrite and barite inclusions (and absence of apatite inclusions) within the carbonate fan crystals (Figs. 5 and 8; Vieira et al., 2015) corroborate this paragenetic sequence, affirming that the inversion of aragonite to calcite occurred concurrently with barite and pyrite formation in the sulfate reduction and/or methanogenesis zones (Fig. 9).

\subsection{Seawater phosphate in the aftermath of glaciation}

The discovery of apatite in the SLF represents a striking outcome of this study. Although P:Fe ratios in iron formations and geochemical models suggest continental weathering during and following low latitude glaciations contributed to high dissolved phosphate concentrations in the ocean (Planavsky et al., 2010; Laakso and Schrag, 2017), and enhanced post-glacial seawater phosphate availability could partly account for the inferred rise in oxygen levels in the Neoproterozoic (Lenton et al., 2014; Laakso and Schrag, 2017), cap carbonates have provided little support for a connection between glaciation and enhanced phosphorus burial (Hoffman et al., 2011). Putative evidence for
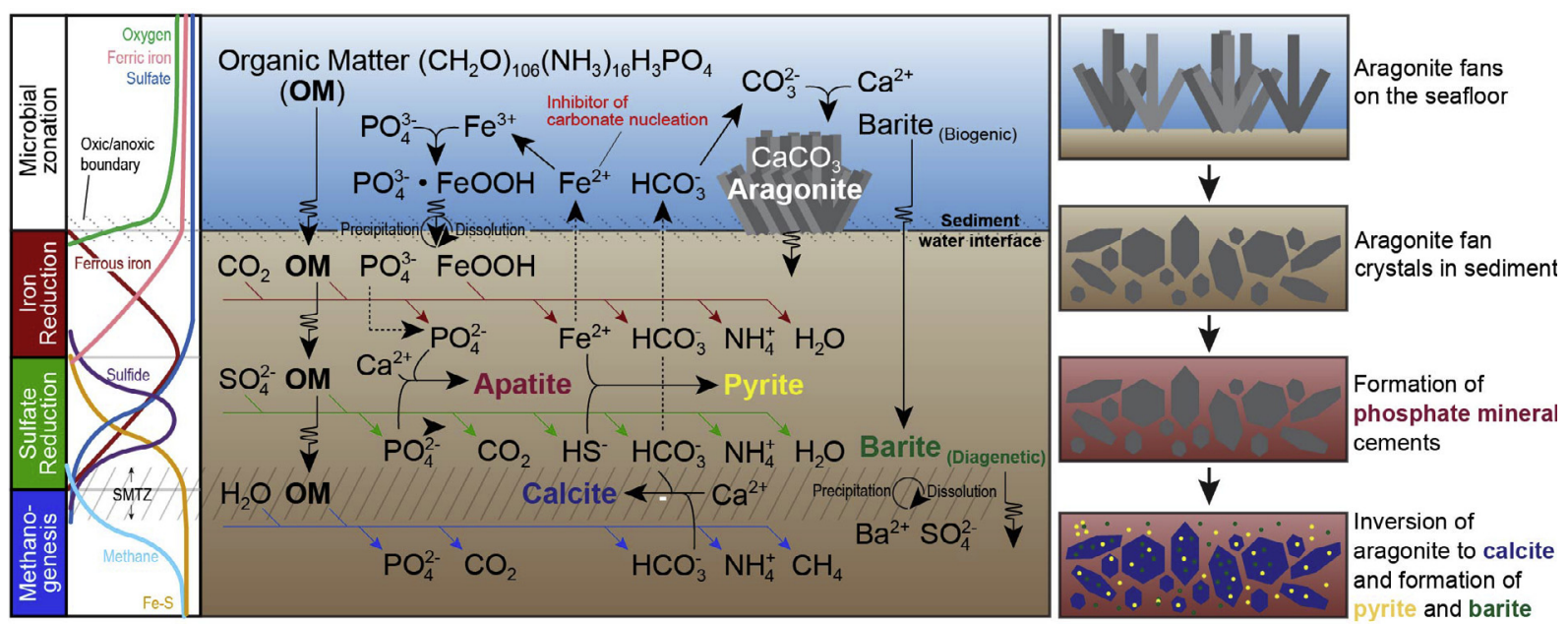

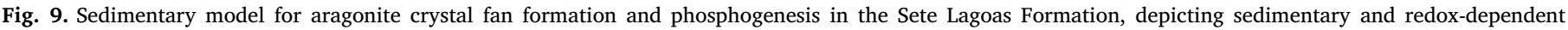

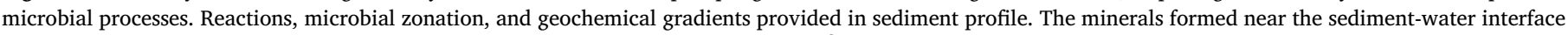

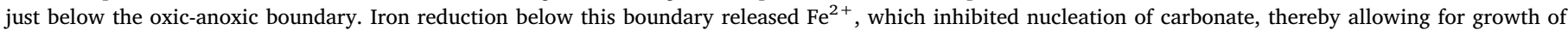

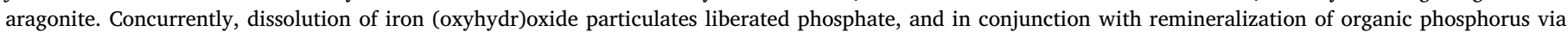

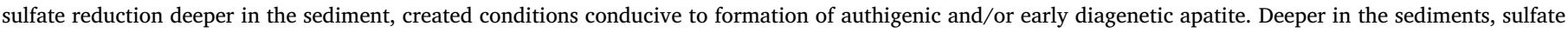
reduction and methanogenesis led to the formation of pyrite, diagenetic microcrstyalline barite, and calcite. OM, organic matter. 
a relationship includes phosphorite overlying cap carbonates in West Africa (Trompette et al., 1980; Bertrand-Sarfati et al., 1997; Shields et al., 2007), South China (Xiao et al., 1998; Zhang et al., 1998; Zhou et al., 2002; Muscente et al., 2015), and Mongolia (Sheldon, 1984; Ilyin et al., 1986; Ilyin, 2009; Macdonald and Jones, 2011). In most cases, however, stratigraphic continuity between cap carbonate and phosphorite remains tenuous (Hoffman et al., 2011). The absence of phosphorite and phosphatic minerals in cap carbonates is therefore conspicuous, given the supposedly high seawater phosphate concentrations that developed in association with low latitude glaciation. Unfortunately, the newly discovered apatitic cements in the SLF do not fill this knowledge gap, as they may reflect local or regional phenomena, like many other phosphatic rocks in Neoproterozoic successions (She et al., 2014; Drummond et al., 2015; Muscente et al., 2015; Cui et al., 2016; Caird et al., 2017). High ocean alkalinity during deposition of cap carbonates likely limited development of the broad and long-lived phosphogenic conditions that became established later in the Ediacaran (Cook and Shergold, 1986; Cook, 1992; Drummond et al., 2015; Muscente et al., 2015; Caird et al., 2017). Even so, phosphate mineral cements in the SLF cap carbonate indicate that such circumstances did not preclude the formation of localized phosphate deposits within cap carbonates. Consequently, future studies may begin to fill the knowledge gap by targeting particular cap carbonate microfacies for petrographic and in situ geochemical analyses. Given the roles that iron (oxyhydr)oxides play in the aragonite fan formation and phosphogenesis, microfacies containing carbonate fan crystals merit particular attention in future investigations.

\section{Conclusions}

The base of the Sete Lagoas Formation cap carbonate (São Francisco craton, Brazil) preserves a record of geochemical, biological, and oceanographic changes that occurred during the Ediacaran Period and contains seafloor precipitates as well as distinct authigenic and diagenetic minerals. Our work explores the significance of these minerals for global seawater chemistry and sedimentary environments following Neoproterozoic glaciations.

- For the first time, this study documents isopachous and void-filling apatitic cements in a Neoproterozoic cap carbonate. These cements occur with carbonate fan crystals within strata correlated with the base of the Sete Lagoas Formation, which contains lithological features (e.g., aragonite and barite crystal fans and basal pink dolostone), carbon and oxygen isotope profiles, and ${ }^{87} \mathrm{Sr} /{ }^{86} \mathrm{Sr}$ ratios (0.7074-0.7076) consistent with Marinoan cap carbonates (Halverson et al., 2005; Hoffman et al., 2007; Caxito et al., 2012).

- The carbonate fan crystals consist of pseudohexagonal calcite units, representing pseudomorphs after aragonite. These minerals formed near the sediment-water interface below the boundary between oxic seawater and anoxic pore water. Iron reduction at this boundary released $\mathrm{Fe}^{2+}$, which inhibited nucleation of micritic carbonate, thereby allowing for formation of aragonite. Concurrently, dissolution of iron (oxyhydr)oxide particulates liberated phosphate bound to their surfaces, and perhaps in conjunction with remineralization of organic phosphorus via sulfate reduction deeper in the sediment, created conditions conducive to formation of the authigenic and/or early diagenetic phosphate minerals.

- Taken altogether, this model suggests that aragonite crystal fans in Neoproterozoic cap carbonates primarily incorporated alkalinity from well-mixed seawater rather than microbially and diagenetically influenced pore water, and corroborates the hypothesis that, in addition to high alkalinity, the presence of inhibitors to carbonate nucleation $\left(\mathrm{Fe}^{2+}\right)$ was a prerequisite for their formation. In addition, given the inferred role of iron reduction, the model suggests that aragonite fans may track seafloors intersected by oxicanoxic redox boundaries through stratigraphic and geographic space.

- Lastly, this study records a rare but expected occurrence of phosphogenesis following a low latitude Neoproterozoic glaciation. Cap carbonates generally provide little support for a connection between glaciation and phosphorus burial. Nonetheless, future studies may begin to fill this knowledge gap by targeting cap carbonate microfacies containing carbonate fan crystals, given the role that iron reduction played in the origins of both apatite and aragonite in the Sete Lagoas Formation.

\section{Acknowledgements}

We would like to thank Hamilton dos Reis Sales for his support in the field and Andy Knoll for helpful comments that helped us to improve the quality of this manuscript. We would also like to thank the State of São Paulo Research Foundation (FAPESP grant 2015/07391-0), the State of Minas Gerais Research Foundation (FAPEMIG project APQ01711-14), National Council for Scientific and Technological Development (CNPq grants 444070/2014-1 and 447449/2014-1) and Petrobras (Sigitec 2014/-00519-9) for financial support. We additionally thank Huan Cui for the constructive comments that helped us to improve this manuscript. Randall Parrish is also acknowledged for handling the manuscript and for giving insightful comments on the manuscript. This research was conducted with institutional support of the São Paulo State University-UNESP, Brazil. L.V. Warren is fellow of the CNPq. A. D. Muscente is supported by the Keck Foundation-funded project "The Co-Evolution of the Geo- and Biospheres: An Integrated Program for Data-Driven Abductive Discovery in Earth Sciences."

\section{References}

Agrella-Filho, M.S.D., Babinski, M., Trindade, R.I.F., Van Schmus, W.R., Ernesto, M. 2000. Simultaneous remagnetization and U-Pb isotope resetting in Neoproterozoic carbonates of the São Francisco craton, Brazil. Precambr. Res. 99, 179-196.

Allison, P.A., 1988. Konservat-Lagerstätten: cause and classification. Paleobiology 14, 331-344.

Arning, E.T., Birgel, D., Brunner, B., Peckmann, J., 2009. Bacterial formation of phosphatic laminites off Peru. Geobiology 7, 295-307. http://dx.doi.org/10.1111/j.1472 4669.2009.00197.x.

Babinski, M., Van Schmus, W.R., Chemale, F., 1999. Pb-Pb dating and $\mathrm{Pb}$ isotope geochemistry of Neoproterozoic carbonate rocks from the Sao Francisco basin, Brazil: implications for the mobility of $\mathrm{Pb}$ isotopes during tectonism and metamorphism. Chem. Geol. 160, 175-199. http://dx.doi.org/10.1016/S0009-2541(99)00067-4.

Babinski, M., Vieira, L.C., Trindade, R.I.F., 2007. Direct dating of the Sete Lagoas cap carbonate (Bambuí Group, Brazil) and implications for the Neoproterozoic glacial events. Terra Nova 19, 401-406. http://dx.doi.org/10.1111/j.1365-3121.2007. 00764.x.

Bergmann, K.D., Grotzinger, J.P., Fischer, W.W., 2013. Biological influences on seafloor carbonate precipitation. Palaios 28, 99-115. http://dx.doi.org/10.2110/palo.2012 p12-088r.

Bertrand-Sarfati, J., Flicoteaux, R., Moussine-Pouchkine, A., Ahmed, A.A.K., 1997. Lower Cambrian apatitic stromatolites and phospharenites related to the glacio-eustatic cratonic rebound (Sahara, Algeria). J. Sediment. Res. 67.

Briggs, D.E.G., Wilby, P.R., 1996. The role of calcium carbonate-calcium phosphate switch in the mineralization of soft-bodied fossils. J. Geol. Soc., London 153, 665-668.

Brito Neves, B.B.D., da Costa Campos Neto, M., Fuck, R.A., 1999. From Rodinia to western Gondwana; an approach to the Brasiliano-Pan African cycle and orogenic collage. Episodes 22, 155-166.

Caird, R.A., Pufahl, P.K., Hiatt, E.E., Abram, M.B., Dourado, A.R., Kyser, T.K., 2017. Ediacaran stromatolites and intertidal phosphorite of the Salitre formation, Brazil: phosphogenesis during the Neoproterozoic oxygenation event. Sed. Geol. 350, 55-71. http://dx.doi.org/10.1016/j.sedgeo.2017.01.005.

Caxito, F.de A., Halverson, G.P., Uhlein, A., Stevenson, R., Gonçalves Dias, T., Uhlein, G.J., 2012. Marinoan glaciation in east central Brazil. Precambr. Res. 200-203, 38-58. http://dx.doi.org/10.1016/j.precamres.2012.01.005.

Chang, H.K., Miranda, F.P., Magalhães, L., Alkmim, F.F., 1988. Considerações sobre a evolução tectônica da bacia do São Francisco. In: Proceedings of the 35th Congresso Brasileiro de Geologia. Sociedade Brasileira de Geologia (SBG), Belém, pp. 2076-2090.

Chiavegatto, J.R.S., 1992. Análise estratigráfica das sequências tempestíticas da Fm. Três Marias (Proterozoico Superior) na porção meridional da bacia do São Francisco.

Cook, P.J., 1992. Phosphogenesis around the Proterozoic-Phanerozoic transition. Journal of the Geological Society 149, 615-620.

Cook, P.J., Shergold, J.H., 1986. Phosphate deposits of the world Vol. 1 Cambridge University Press, Cambridge. 
Corsetti, F.A., Lorentz, N.J., 2006. On Neoproterozoic Cap Carbonates as Chronostratigraphic Markers. In: Xiao, S., Kaufman, A.J. (Eds.), Neoproterozoic Geobiology and Paleobiology. pp. 273-294.

Corsetti, F.A., Lorentz, N.J., Pruss, S.B., 2004. Formerly-Aragonite Seafloor Fans from Neoproterozoic Strata, Death Valley and Southeastern Idaho, United States: Implications for "Cap Carbonate" Formation and Snowball Earth. The Extreme Proterozoic: Geology, Geochemistry, and Climate, pp. 33-44. doi: 10.1029/ $146 \mathrm{GM} 04$.

Creveling, J.R., Johnston, D.T., Poulton, S.W., Kotrc, B., März, C., Schrag, D.P., Knoll, A.H., 2014. Phosphorus sources for phosphatic Cambrian carbonates. Bull. Geol. Soc. Am. 126, 145-163. http://dx.doi.org/10.1130/B30819.1.

Crockford, P.W., Cowie, B., Johnston, D.T., Macdonald, F.A., 2016. Triple oxygen and multiple sulfur isotope constraints on the evolution of the post-Marinoan sulfur cycle. Earth Planet. Sci. Lett. 435, 74-83. http://dx.doi.org/10.1016/j.epsl.2015.12.017.

Crockford, P.W., Hodgskiss, M.S.W., Uhlein, G.J., Caxito, F., Hayles, J.A., Halverson, G.P., 2017. Linking paleocontinents through triple oxygen isotope anomalies. Geology 46 (2), 179-182. http://dx.doi.org/10.1130/G39470.1 |.

Cruz, N.M.C., Nobre-Lopes, J., 1992. Microfósseis do Grupo Bambuí na região de Arcos, Minas Gerais. An. Acad. Bras. Cienc. 64, 420

Cui, H., Xiao, S., Zhou, C., Peng, Y., Kaufman, A.J., Plummer, R.E., 2016. Phosphogenesis associated with the Shuram Excursion: petrographic and geochemical observations from the Ediacaran Doushantuo formation of South China. Sediment. Geol. 341, 134-146. http://dx.doi.org/10.1016/j.sedgeo.2016.05.008.

Cui, H., Kaufman, A.J., Xiao, S., Zhou, C., Liu, X.-M., 2017. Was the Ediacaran Shuram Excursion a globally synchronized early diagenetic event? Insights from methanederived authigenic carbonates in the uppermost Doushantuo Formation, South China. Chem. Geol. 450, 59-80. http://dx.doi.org/10.1016/j.chemgeo.2016.12.010.

Dardenne, M.A., 1978. Síntese sobre a estratigrafia do Grupo Bambuí no Brasil Central. In: Congresso Brasileiro de Geologia, 30. Anais, Recife, Brazil, pp. 597-610.

De Leeuw, N.H., 2002. Molecular dynamics simulations of the growth inhibiting effect of $\mathrm{Fe} 2+, \mathrm{Mg} 2+, \mathrm{Cd} 2+$, and Sr2 + on calcite crystal growth. J. Phys. Chem. B 106, $5241-5249$.

Deynoux, M., 1985. Terrestrial or waterlain glacial diamictites? Three case studies from the Late Precambrian and Late Ordovician glacial drifts in West Africa. Palaeogeogr. Palaeoclimatol. Palaeoecol. 51, 97-141.

Drummond, J.B.R., Pufahl, P.K., Porto, C.G., Carvalho, M., 2015. Neoproterozoic peritidal phosphorite from the Sete Lagoas Formation (Brazil) and the Precambrian phosphorus cycle. Sedimentology 62, 1978-2008. http://dx.doi.org/10.1111/sed.12214.

Evans, D.A.D., Raub, T.D., 2011. Neoproterozoic glacial palaeolatitudes: a global update. Geol. Rec. Neoproter. Glaciat. 93-112. http://dx.doi.org/10.1144/M36.7.

Eyles, N., Januszczak, N., 2004. "Zipper-rift": a tectonic model for Neoproterozoic glaciations during the breakup of Rodinia after 750 Ma. Earth Sci. Rev. 65, 1-73. http:// dx.doi.org/10.1016/S0012-8252(03)00080-1.

Fairchild, I.J., Kennedy, M.J., 2007. Neoproterozoic glaciation in the Earth System. J. Geol. Soc., London 164, 895-921. http://dx.doi.org/10.1144/0016-76492006-191.

Fairchild, T.R., Schopf, J.W., Shen-Miller, J., Guimarães, E.M., Edwards, M.D., Lagstein, A., Xiao, L., Pabst, M., Melo-Filho, L.S., 1996. Recent discoveries of Proterozoic microfossils in south-central Brazil. Precambr. Res. 80, 125-152. http://dx.doi.org/10. 1016/S0301-9268(96)00009-5

Fairchild, T.R., Subacius, S.M.R., 1986. Microfossils associated with silicified Stratifera undata Komar 1966 from the Late Proterozoic Bambuí Group, south-central Brazil. Precambr. Res. 33, 323-339.

Föllmi, K.B., 1996. The phosphorus cycle, phosphogenesis and marine phosphate-rich deposits. Earth Sci. Rev. 40, 55-124.

Glenn, C.R., Arthur, M.A., 1990. Anatomy and origin of a Cretaceous phosphoritegreensand giant, Egypt. Sedimentology 37, 123-154. http://dx.doi.org/10.1111/j. 1365-3091.1990.tb01986.x.

Glenn, C.R., Föllmi, K.B., Grimm, K.A., Sadaqah, R.M.Y., Schidlowski, M., Sheldon, R.E., Siegmund, H., 1994. Phosphorus and phosphorites: sedimentology and environments of formation. Eclog. Geol. Helv. 87, 747-788.

Griffith, E.M., Paytan, A., 2012. Barite in the ocean - occurrence, geochemistry and palaeoceanographic applications. Sedimentology 59, 1817-1835. http://dx.doi.org/10. 1111/j.1365-3091.2012.01327.x.

Grotzinger, J.P., Knoll, A.H., 1995. Anomalous carbonate precipitates: is the Precambrian the key to the Permian? Palaios 10, 578-596.

Hagadorn, J.W., Waggoner, B., 2000. Ediacaran fossils from the Southwestern Great Basin, United States. J. Paleontol. 74, 349-359. http://dx.doi.org/10.1666/0022 3360(2000) $074<0349$ :EFFTSG > 2.0.CO;2.

Hahn, G., Hahn, R., Leonardos, O.H., Pflug, H.D., Walde, D.H.G., 1982. Körperlich erhaltene Scyphozoen-Reste aus dem Jungpräkambrium Brasiliens. Geol. Paleontol. 16, $1-18$.

Halverson, G.P., Hoffman, P.F., Schrag, D.P., Maloof, A.C., Rice, A.H.N., 2005. Toward a Neoproterozoic composite carbon-isotope record. Bull. Geol. Soc. Am. 117, 1181-1207. http://dx.doi.org/10.1130/B25630.1.

Higgins, J.A., Schrag, D.P., 2003. Aftermath of a snowball earth. Geochem. Geophys. Geosyst. 4, 1-20. http://dx.doi.org/10.1029/2002GC000403.

Hoffman, P.F., 2011. Strange bedfellows: Glacial diamictite and cap carbonate from the Marinoan (635Ma) glaciation in Namibia. Sedimentology 58, 57-119. http://dx.doi. org/10.1111/j.1365-3091.2012.01360.x.

Hoffman, P.F., Halverson, G.P., 2011. Neoproterozoic glacial record in the Mackenzie Mountains, northern Canadian Cordillera. Geol. Soc., London Memoirs 36, 397-412.

Hoffman, P.F., Halverson, G.P., Domack, E.W., Husson, J.M., Higgins, J.A., Schrag, D.P., 2007. Are basal Ediacaran (635 Ma) post-glacial "cap dolostones" diachronous? Earth Planet. Sci. Lett. 258, 114-131. http://dx.doi.org/10.1016/j.epsl.2007.03.032.

Hoffman, P.F., Kaufman, A.J., Halverson, G.P., Schrag, D.P., 1998. A Neoproterozoic snowball earth. Science 281, 1342-1346. http://dx.doi.org/10.1126/science.281.
5381.1342.

Hoffman, P.F., Macdonald, F.a., Halverson, G.P., 2011. Chemical sediments associated with Neoproterozoic glaciation: iron formation, cap carbonate, barite and phosphorite. Geol. Soc., London Memoirs 36, 67-80. http://dx.doi.org/10.1144/M36.5. Hoffman, P.F., Schrag, D.P., 2002. The snowball Earth hypothesis: testing the limits of global change. Terra Nova 14, 129-155. http://dx.doi.org/10.1080/713604466.

Ilyin, A.V., 2009. Neoproterozoic banded iron formations. Lithol. Min. Resour. 44, 78-86.

Ilyin, A.V., Zaitsev, N.S., Bjamba, Z., 1986. Khubsugul, Mongolia people's republic. In: Cook, P.J., Sheldon, J.H. (Eds.), Phosphate Deposits of the World. Proterozoic and Cambrian Phosphorites. Cambridge University Press, Cambridge.

James, N.P., Narbonne, G.M., Kyser, T.K., 2001. Late Neoproterozoic cap carbonates: Mackenzie Mountains, northwestern Canada: precipitation and global glacial meltdown. Can. J. Earth Sci. 38, 1229-1262. http://dx.doi.org/10.1139/cjes-38-8-1229.

Jiang, G., Kennedy, M.J., Christie-Blick, N., 2003. Stable isotopic evidence for methane seeps in Neoproterozoic postglacial cap carbonates. Nature 426, 822-826. http://dx. doi.org/10.1038/nature02201.

Jiang, G., Kennedy, M.J., Christie-Blick, N., Wu, H., Zhang, S., 2006a. Stratigraphy, sedimentary structures, and textures of the late Neoproterozoic Doushantuo Cap carbonate in South China. J. Sediment. Res. 76, 978-995. http://dx.doi.org/10.2110/ jsr.2006.086.

Jiang, G., Shi, X., Zhang, S., 2006b. Methane seeps, methane hydrate destabilization, and the late Neoproterozoic postglacial cap carbonates. Chin. Sci. Bull. 51, 1152-1173. http://dx.doi.org/10.1007/s11434-006-1152-y.

Kastner, M., 1999. Oceanic minerals: their origin, nature of their environment, and significance. PNAS 96, 3380-3387. http://dx.doi.org/10.1073/pnas.96.7.3380.

Kaufman, A.J., Knoll, A.H., Narbonne, G.M., 1997. Isotopes, ice ages, and terminal Proterozoic earth history. Geology 94, 6600-6605. http://dx.doi.org/10.1073/pnas. 94.13.6600.

Kaufman, A.J., Sial, A.N., Frimmel, H.E., Misi, A., 2009. Neoproterozoic to Cambrian palaeoclimatic events in southwestern Gondwana. In: Gaucher, C., Sial, A.N., Frimmel, H.E., Halverson, G.P. (Eds.), Developments in Precambrian Geology. Elsevier, Amsterdam, Netherlands, pp. 369-388. http://dx.doi.org/10.1016/s0166 2635(09)01626-0.

Kennedy, M.J., 1996. Stratigraphy, sedimentology, and isotopic geochemistry of Australian Neoproterozoic postglacial cap dolostones: deglaciation, D13C excursions, and carbonate precipitation. J. Sediment. Res. 66, 1050-1064.

Kennedy, M.J., Christie-Blick, N., Sohl, L.E., 2001. Are Proterozoic cap carbonates and isotopic excursions a record of gas hydrate destabilization following Earth's coldest intervals? Geology 29, 443-446. http://dx.doi.org/10.1130/0091-7613(2001) $029<0443$ :APCCAI > 2.0.CO.

Kennedy, M.J., Runnegar, B., Prave, A.R., Hoffman, K.-H., Arthur, M.A., 1998. Two or four Neoproterozoic glaciations? Geology 26, 1059-1063.

Kirschvink, J.L., 1992. Late Proterozoic low-latitude global glaciation: the snowbal Earth. In: Schopf, J.W., Klein, C. (Eds.), The Proterozoic Biosphere. Cambridge University Press, Cambridge, pp. 51-52.

Kuchenbecker, M., Babinski, M., Pedrosa-Soares, A.C., Lopes-Silva, L., Pimenta, F., 2016. Chemostratigraphy of the lower Bambuí Group, southwestern São Francisco Craton, Brazil: insights on Gondwana paleoenvironments. Braz. J. Geol. 46, 145-162. http:// dx.doi.org/10.1590/2317-488920160030285.

Laakso, T.A., Schrag, D.P., 2017. A theory of atmospheric oxygen. Geobiology 15 366-384. http://dx.doi.org/10.1111/gbi.12230.

Lenton, T.M., Boyle, R.A., Poulton, S.W., Shields-zhou, G.A., Butterfield, N.J., 2014. Coevolution of eukaryotes and ocean oxygenation in the Neoproterozoic era. Nat. Geosci. 7, 257-265. http://dx.doi.org/10.1038/NGEO2108.

Lorentz, N.J., Corsetti, F.A., Link, P.K., 2004. Seafloor precipitates and C-isotope stratigraphy from the Neoproterozoic Scout Mountain Member of the Pocatello Formation, southeast Idaho: Implications for Neoproterozoic earth system behavior. Precambr. Res. 130, 57-70. http://dx.doi.org/10.1016/j.precamres.2003.10.017.

Macdonald, F.A., Jones, D.S., 2011. The Khubsugul Group, Northern Mongolia. In: The Geological Record of Neoproterozoic Glaciations. pp. 339-345.

Macdonald, F.A., Mcclelland, W.C., Schrag, D.P., Macdonald, W.P., Macdonald, F.A., Mcclelland, W.C., Schrag, D.P., Macdonald, W.P., 2009. Neoproterozoic glaciation on a carbonate platform margin in Arctic Alaska and the origin of the North Slope subterrane. GSA Bull. 121, 448-473. http://dx.doi.org/10.1130/B26401.1.

Macdonald, F.A., Strauss, J.V., Sperling, E.A., Halverson, G.P., Narbonne, G.M., Johnston, D.T., Kunzmann, M., Schrag, D.P., Higgins, J.A., 2013. The stratigraphic relationship between the Shuram carbon isotope excursion, the oxygenation of Neoproterozoic oceans, and the first appearance of the Ediacara biota and bilaterian trace fossils in northwestern Canada. Chem. Geol. 362, 250-272. http://dx.doi.org/10.1016/j. chemgeo.2013.05.032.

Marchese, H.G., 1974. Estromatólitos "Gymnosolenideos" em el lado oriental de Minas Gerais, Brasil. Revista Brasileira de Geociências 4, 257-271.

Martins-Neto, M.A., 2009. Sequence stratigraphic framework of Proterozoic successions in eastern Brazil. Mar. Pet. Geol. 26, 163-176. http://dx.doi.org/10.1016/j marpetgeo.2007.10.001.

McFadden, K.A., Huang, J., Chu, X., Jiang, G., Kaufman, A.J., Zhou, C., Yuan, X., Xiao, S. 2008. Pulsed oxidation and biological evolution in the Ediacaran Doushantuo Formation. Proc. Natl. Acad. Sci. U.S.A. 105, 3197-3202. http://dx.doi.org/10.1073/ pnas.0708336105.

McMechan, M.E., 2000. Vreeland Diamictites - Neoproterozoic glaciogenic slope deposits, Rocky Mountains, northeast British Columbia. Bull. Can. Pet. Geol. 48, $246-261$.

Meert, J.G., van der Voo, R., 1994. The Neoproterozoic (1000-540 Ma) glacial intervals: No more snowball earth? Earth Planet. Sci. Lett. 123, 1-13. http://dx.doi.org/10 1016/0012-821X(94)90253-4.

Misi, A., Veizer, J., 1998. Neoproterozoic carbonate sequences of the Una Group, Irecê 
Basin, Brazil: chemostratigraphic, age and correlations. Precambr. Res. 89, 87-100.

Misi, A., Kaufman, A.J., Veizer, J., Powis, K., Azmy, K., Boggiani, P.C., Gaucher, C., Teixeira, J.B.G., Sanches, A.L., Iyer, S.S., 2007. Chemostratigraphic correlation of Neoproterozoic successions in South America. Chem. Geol. 237, 143-167. http://dx. doi.org/10.1016/j.chemgeo.2006.06.019.

Muscente, A.D., Hawkins, A.D., Xiao, S., 2015. Fossil preservation through phosphatization and silicification in the Ediacaran Doushantuo Formation (South China): A comparative synthesis. Palaeogeogr. Palaeoclimatol. Palaeoecol. 434, 46-62. http:// dx.doi.org/10.1016/j.palaeo.2014.10.013.

Muscente, A.D., Xiao, S., 2015. Resolving three-dimensional and subsurficial features of carbonaceous compressions and shelly fossils using backscattered electron scanning electron microscopy (BSE-SEM). Palaios 30, 462-481. http://dx.doi.org/10.2110/ palo.2014.094.

Myrow, P.M., Kaufman, A.J., 1999. A newly discovered cap carbonate above Varangerage glacial deposits in Newfoundland, Canada. J. Sediment. Res. 69, 784-793. http:// dx.doi.org/10.2110/jsr.69.784.

Nelson, G.J., Pufahl, P.K., Hiatt, E.E., 2010. Paleoceanographic constraints on Precambrian phosphorite accumulation, Baraga Group, Michigan, USA. Sed. Geol. 226, 9-21. http://dx.doi.org/10.1016/j.sedgeo.2010.02.001.

Nobre-Lopes, J., Coimbra, A.M., 2000. Microfitólitos associados a construç̃es estromatolíticas do Grupo Bambuí, Proterozóico Superior, na região de Arcos - MG. Rev. Bras. Geocien. 30, 589-592.

Nogueira, A.C.R., Riccomini, C., Nóbrega Sial, A., Veloso Moura, C.A., Fairchild, T.R. 2003. Soft-sediment deformation at the base of the Neoproterozoic Puga cap carbonate (southwestern Amazon craton, Brazil): Confirmation of rapid icehouse to greenhouse transition in snowball Earth. Geology 31, 613-616. http://dx.doi.org/10. 1130/0091-7613(2003) 031<0613:SDATBO > 2.0.CO;2.

Papineau, D., 2010. Global biogeochemical changes at both ends of the proterozoic: insights from phosphorites. Astrobiology 10, 165-181. http://dx.doi.org/10.1089/ast. 2009.0360.

Paula-Santos, G.M., Babinski, M., Kuchenbecker, M., Caetano-Filho, S., Trindade, R.I., Pedrosa-Soares, A.C., 2015. New evidence of an Ediacaran age for the Bambuí Group in southern São Francisco craton (eastern Brazil) from zircon U-Pb data and isotope chemostratigraphy. Gondwana Res. 28, 702-720. http://dx.doi.org/10.1016/j.gr. 2014.07.012

Paytan, A., Mearon, S., Cobb, K., Kastner, M., 2002. Origin of marine barite deposits: Sr and S isotope characterization. Geology 30, 747-750. http://dx.doi.org/10.1130/ 0091-7613(2002) $030<0747$ :OOMBDS $>2.0$. CO;2.

Peryt, T.M., Hoppe, A., Bechstädt, T., Koster, J., Pierre, C., Richter, D.K., 1990. Late Proterozoic aragonitic cement crusts, Bambui Group, Minas Gerais, Brazil. Sedimentology 37, 279-286. http://dx.doi.org/10.1111/j.1365-3091.1990. tb00959.x.

Pimentel, M.M., Dardenne, M.A., Fuck, R.A., Viana, M.G., Junges, S.L., Fischel, D.P., Seer, H.J., Dantas, E.L., 2001. Nd isotopes and the provenance of detrital sediments of the Neoproterozoic Brasília Belt, central Brazil. J. S. Am. Earth Sci. 14, 571-585.

Pimentel, M.M., Rodrigues, J.B., DellaGiustina, M.E.S., Junges, S., Matteini, M., Armstrong, R., 2011. The tectonic evolution of the Neoproterozoic Brasília Belt, central Brazil, based on SHRIMP and LA-ICPMS U-Pb sedimentary provenance data: A review. J. S. Am. Earth Sci. 31, 345-357. http://dx.doi.org/10.1016/j.jsames.2011. 02.011

Planavsky, N.J., Rouxel, O.J., Bekker, A., Lalonde, S.V., Konhauser, K.O., Reinhard, C.T., Lyons, T.W., 2010. The evolution of the marine phosphate reservoir. Nature 467 1088-1090. http://dx.doi.org/10.1038/nature09485.

Pruss, S.B., Corsetti, F.A., Fischer, W.W., 2008. Seafloor-precipitated carbonate fans in the Neoproterozoic Rainstorm Member, Johnnie formation, Death Valley Region, USA Sed. Geol. 207, 34-40. http://dx.doi.org/10.1016/j.sedgeo.2008.03.005

Pu, J.P., Bowring, S.A., Ramezani, J., Myrow, P., Raub, T.D., Landing, E., Mills, A., Hodgin, E., Macdonald, F.A., 2016. Dodging snowballs: Geochronology of the Gaskiers glaciation and the first appearance of the Ediacaran biota. Geology 44, 955-958. http://dx.doi.org/10.1130/G38284.1.

Reis, H.L.S., Suss, J.F., 2016. Mixed carbonate-siliciclastic sedimentation in forebulge grabens: An example from the Ediacaran Bambuí Group, São Francisco Basin, Brazil. Sed. Geol. 339, 83-103. http://dx.doi.org/10.1016/j.sedgeo.2016.04.004.

Ridgwell, A.J., Kennedy, M.J., Caldeira, K., 2003. Carbonate Deposition, Climate Stability, and Neoproterozoic Ice Ages. Science 302, 859-862. http://dx.doi.org/10. 1126 /science. 1088342 .

Rodrigues, J.B., 2008. Proveniência de sedimentos dos grupos Canastra, Ibiá, Vazante e Bambuí - Um estudo de zircões detríticos e Idades Modelo Sm-Nd. Universidade de Brasília.

She, Z.B., Strother, P., Papineau, D., 2014. Terminal Proterozoic cyanobacterial blooms and phosphogenesis documented by the Doushantuo granular phosphorites II:
Microbial diversity and C isotopes. Precambr. Res. 251, 62-79. http://dx.doi.org/10. 1016/j.precamres.2014.06.004.

Sheldon, R.P., 1984. Ice-ring origin of the Earth's atmosphere and hydrosphere and Late Proterozoic-Cambrian hypothesis. Geol. Surv. India Spec. Publ. 17, 17-21.

Shields, G.A., Deynoux, M., Strauss, H., Nahon, D., 2007. Barite-bearing cap dolostones of the Taoudéni Basin, northwest Africa: Sedimentary and isotopic evidence for methane seepage after a Neoproterozoic glaciation. Precambr. Res. 153, 209-235. http://dx.doi.org/10.1016/j.precamres.2006.11.011.

Spence, G.H., Heron, D. Le, Fairchild, I., 2016. Sedimentological perspectives on climatic, atmospheric and environmental change in the Neoproterozoic Era. Sedimentology 63, 253-306. http://dx.doi.org/10.1111/sed.12261.

Sumner, D.Y., Grotzinger, J.P., 2004. Implications for Neoarchean ocean chemistry from primary carbonate mineralogy of the Campbell-Malmani Platform, South Africa Sedimentology 51, 1-27.

Sumner, D.Y., Grotzinger, J.P., 1996. Herringbone calcite: petrology and environmental significance. J. Sediment. Res. 66.

Trindade, R.I.F., Macouin, M., 2007. Palaeolatitude of glacial deposits and palaeogeography of Neoproterozoic ice ages. C. R. Geosci. 339, 200-211. http://dx.doi.org/10. 1016/j.crte.2007.02.006.

Trompette, R., Affaton, P., Joulia, F., Marchand, J., 1980. Stratigraphic and structural controls of late Precambrian phosphate deposits of the northern Volta Basin in Upper Volta, Niger, and Benin, West Africa. Econ. Geol. 75, 62-70.

Trompette, R.R., 1994. Geology of Western Gondwana (2000-500 Ma): Pan-African Brasiliano aggregation of South America and Africa.

Uhlein, G.J., Uhlein, A., Halverson, G.P., Stevenson, R., Caxito, F.A., Cox, G.M., Carvalho, J.F.M.G., 2016. The Carrancas formation, Bambuí Group: a record of pre-Marinoan sedimentation on the southern São Francisco craton, Brazil. J. S. Am. Earth Sci. 71, 1-16. http://dx.doi.org/10.1016/j.jsames.2016.06.009.

van Loon, A.J., 2008. Could "Snowball Earth" have left thick glaciomarine deposits? Gondwana Res. 14, 73-81. http://dx.doi.org/10.1016/j.gr.2007.05.009.

Vieira, L.C., Nédélec, A., Fabre, S., Trindade, R.I.F., Almeida, R.P.D.E., 2015. Aragonite crystal fans in Neoproterozoic cap carbonates: a case study from Brazil and implications for the post - snowball earth coastal environment. J. Sediment. Res. 85, 285-300. http://dx. doi.org/10.2110/jsr.2015.21.

Vieira, L.C., Trindade, R.I.F., Nogueira, A.C.R., Ader, M., 2007. Identification of a Sturtian cap carbonate in the Neoproterozoic Sete Lagoas carbonate platform, Bambuí Group Brazil. C. R. Geosci. 339, 240-258. http://dx.doi.org/10.1016/j.crte.2007.02.003.

Warren, L.V., Fairchild, T.R., Gaucher, C., Boggiani, P.C., Poiré, D.G., Anelli, L.E. Inchausti, J.C.G., 2011. Corumbella and in situ Cloudina in association with throm bolites in the Ediacaran Itapucumi Group, Paraguay. Terra Nova 23, 382-389. http:// dx.doi.org/10.1111/j.1365-3121.2011.01023.x.

Warren, L.V., Quaglio, F., Riccomini, C., Simões, M.G., Poiré, D.G., Strikis, N.M., Anelli, L.E., Strikis, P.C., 2014. The puzzle assembled: Ediacaran guide fossil Cloudina reveals an old proto-Gondwana seaway. Geology 42, 391-394. http://dx.doi.org/10 $1130 / \mathrm{G} 35304.1$

Xiao, S., Muscente, A.D., Chen, L., Zhou, C., Schiffbauer, J.D., Wood, A.D., Polys, N.F., Yuan, X., 2014. The Weng'an biota and the Ediacaran radiation of multicellular eukaryotes. Natl. Sci. Rev. 1, 498-520. http://dx.doi.org/10.1093/nsr/nwu061.

Xiao, S., Narbonne, G.M., Zhou, C., Laflamme, M., Grazhdankin, D.V., MoczydlowskaVidal, M., Cui, H., 2016. Towards an Ediacaran time scale: problems, protocols, and prospects. Episodes 39, 540. http://dx.doi.org/10.18814/epiiugs/2016/v39i4/ 103886.

Xiao, S., Schiffbauer, J.D., McFadden, K.A., Hunter, J., 2010. Petrographic and SIMS pyrite sulfur isotope analyses of Ediacaran chert nodules: implications for microbial processes in pyrite rim formation, silicification, and exceptional fossil preservation. Earth Planet. Sci. Lett. 297, 481-495. http://dx.doi.org/10.1016/j.epsl.2010.07.001.

Xiao, S., Zhang, Y., Knoll, A.H., 1998. Three-dimensional preservation of algae and animal embryos in a Neoproterozoic phosphorite. Nature 391, 553-558. http://dx.doi. org $/ 10.1038 / 35318$

Zhang, Y., Yin, L., Xiao, S., Knoll, A.H., 1998. Permineralized fossils from the terminal proterozoic Doushantuo. J. Paleontol. 72, 1-52.

Zhou, C., Yuan, X., Xiao, S., 2002. Phosphatized biotas from the Neoproterozoic Doushantuo Formation on the Yangtze Platform. Chin. Sci. Bull. 47, 1918-1924. http://dx.doi.org/10.1360/02tb9419.

Zhou, C., Bao, H., Peng, Y., Yuan, X., 2010. Timing the deposition of 17O-depleted barite at the aftermath of Nantuo glacial meltdown in South China. Geology 38, 903-906. http://dx.doi.org/10.1130/g31224.1.

Zhou, X., Chen, D., Dong, S., Zhang, Y., Guo, Z., Wei, H., Yu, H., 2015. Diagenetic barite deposits in the Yurtus formation in Tarim Basin, NW China: implications for barium and sulfur cycling in the earliest Cambrian. Precambr. Res. 263, 79-87. http://dx.doi. org/10.1016/j.precamres.2015.03.006. 